\title{
Palladium Complexes Based on 2-Hydrazinopyridine Ligand: Synthesis, Spectroscopic Studies, DFT Calcullations, and Cytotoxicity
}

\author{
Sattar R. Majeed 1(D), Mina A. Amin 2(D), Fawzy A. Attaby ${ }^{3(\mathbb{D})}$, Ahmed A. Soliman 4,*(i) \\ 1 Department of Chemistry, College of Science, University of Anbar, Ramadi, Anbar, Iraq; sc.sat70tar@uoanbar.edu.iq \\ (S.R.M); \\ 2 Department of Chemistry, Faculty of Science, Cairo University, 12613 Giza, Egypt; mina_anis89@ @otmail.com (M.A.A.); \\ 3 Department of Chemistry, Faculty of Science, Cairo University, 12613 Giza, Egypt; fattaby @ gmail.com (F.A.A); \\ 4 Department of Chemistry, Faculty of Science, Cairo University, 12613 Giza, Egypt; ahmedsoliman61@gmail.com \\ (A.A.S); \\ * Correspondence: ahmedsoliman61@gmail.com;
}

Scopus Author ID 55574193552

Received: 3.02.2021; Revised: 28.02.2021; Accepted: 2.03.2021; Published: 10.03.2021

\begin{abstract}
Three new palladium complexes based on 2-hydrazinopyridine (hzpy) ligand, coupled with oxalate (ox), malonate (ma) and pyrophosphate (pyph) ligands, were prepared; [Pd(hzpy)(ox)], $[\operatorname{Pd}($ hzpy $)(\mathrm{ma})]$ and $[\operatorname{Pd}($ hzpy)(pyph)]. The spectroscopic and thermal studies of the complexes suggested that the complexes were of square planar geometry. The complexes were thermally stable with an overall activation energy of 678, 981, and $633 \mathrm{~kJ}$ mol-1 for [Pd(hzpy)(ox)]. [Pd(hzpy)(ma)] and $[\mathrm{Pd}(\mathrm{hzpy})(\mathrm{pyph})]$, respectively. Geometric optimization of the three complexes was performed at DFT/B3LYP/SDD level through Gaussian 09. TDDFT and frequency calculations were studied to investigate the electronic and vibrational transitions. The potential in vitro cytotoxic activities of the three complexes was studied. The complexes exhibited a moderate cytotoxic effect against four cancer cell lines; MCF-7 (human breast cancer cell line), HepG-2 (human Hepatocellular carcinoma), PC-3 cells (human prostate carcinoma), and HEP-2 (Larynx carcinoma). The IC50 values of the three complexes exhibited a good performance against PC-3 cell line with low IC50 values reached 2.87 $\mu \mathrm{g} / \mathrm{ml}$ for $[\operatorname{Pd}($ hzpy)(ox)] compared to the IC50 of Vinblastine sulfate $(42.4 \mu \mathrm{g} / \mathrm{ml})$.
\end{abstract}

Keywords: palladium complex; dinitrogen ligands; cytotoxicity; DFT.

\section{Abbreviations:}

TGA

Thermal gravimetric analysis

DFT

Density functional theory

TD-DFT

Time-dependent density functional theory

LLCT

Ligand-ligand charge transfer

MLCT

Metal-ligand charge transfer

$\Delta \mathrm{E}$

Energy gap

$\chi$

Absolute electronegativity

$\eta$

Absolute hardness

$\sigma \quad$ absolute softness

Pi chemical potentials

$\omega \quad$ global electrophilicity

S global softness

$\Delta \mathrm{N}_{\max } \quad$ Additional electronic charge

(C) 2021 by the authors. This article is an open-access article distributed under the terms and conditions of the Creative Commons Attribution (CC BY) license (https://creativecommons.org/licenses/by/4.0/). 


\section{Introduction}

Coordination chemistry supported humans with many metal complexes used for different purposes, including catalysis and biological applications (antitumor drugs) [1]. The importance of these applications paved the way to improve and tune the chemical properties of the metal complexes and the accompanying ligands. Cisplatin, carboplatin and oxaliplatin are the main platinum-based compounds used as antitumor agents [2, 3]. Unfortunately, cis-platin, the main antitumor agent, acquired resistance and has toxic effects. Such resistance and toxicity forced researchers to direct their efforts for preparing analogs to cisplatin [4, 5]. The similar properties (structural and thermodynamic) between platinum and palladium (soft Lewis acids) encourage the researchers to prepare new palladium-based analogs to be used as antitumor agents to avoid cisplatin drawbacks [6]. Palladium-based coordinated compounds have higher activity compared to that of the platinum alternatives as they hydrolyze rapidly. The palladium complexes' fast kinetics form reactive spices within the biological systems that cannot reach their targets [7-9]. The ligands' type and nature are critical in tuning the reactivity, stability, and lipophilicity of the metal complexes [10]. The palladium complexes' reactivity requires a smart design for the complexes to stabilize complexes such as using bulky, chelating, and nitrogen-based ligands such as pyridine derivatives imidazole and 1,10-phenanthroline [1114]. Modifying the coordinated ligands to the palladium center can also tune and enhance the palladium complexes' cytotoxic activities [15-20]. The pyridine derivative-based complexes were reported to act as antitumor agents, and the ability of their palladium complexes proved their ability to interact with DNA $[21,22]$. We continue our research on $\mathrm{Pd}(\mathrm{II})$ complexes in the current work, soluble in water, based on 2-hydrazinopyridine ligand with potential antitumor activities. The three palladium complexes' water solubilities were enhanced by coordinating the palladium center ion with oxalate, malonate, and pyrophosphate ligands. The in vitro cytotoxic activities of the palladium complexes were investigated against four cancer cell lines; MCF-7 (human breast cancer cell line), HepG-2 (human Hepatocellular carcinoma), PC-3 cells (human prostate carcinoma), and HEP-2 (Larynx carcinoma), and the IC50 values were recorded. Three palladium complexes were synthesized and characterized using spectroscopic techniques (IR, UV, and NMR) magnetic and thermal analyses. The complexes were optimized at DFT/B3LYP/SDD level.

\section{Materials and Methods}

\subsection{Materials.}

Sodium tetrachloro palladate, sodium pyrophosphate, 2-hydrazinopyridine hydrochloride, malonic acid, and oxalic acid were obtained from Sigma Aldrich.

\subsection{Physical measurements.}

The absorption spectra were collected using an Optizen UV-Vis spectrophotometer. The IR spectra were recorded using a Jasco FT-IR - 460 plus. Varian-Oxford Mercury VX300 NMR (300 MHz) spectrometer was used for ${ }^{1} \mathrm{HNMR}$ spectra (DMSO-d6). FAB-MS measurements of the compounds were performed via JEOL JMS- AX 500 spectrometer. TGA analyses of the three complexes were performed by Shimadzu thermogravimetric analyzer (TGA-50H) under a continuous flow of $\mathrm{N}_{2}$ and heating rate of $10{ }^{\circ} \mathrm{C} / \mathrm{min}$. 


\subsection{Theoretical calculations.}

The geometrical optimization of the palladium complexes (Figures $1-3$ ) in the gas phase was performed at DFT/B3LYP/SDD level [23-27] using GAUSSIAN 09 [28]. The output files were displayed using GaussView 5.0. The frequency and TD-DFT calculations were also investigated. The bond angles and lengths around the metal center are listed in Tables S1 - S3 (Supplementary materials).

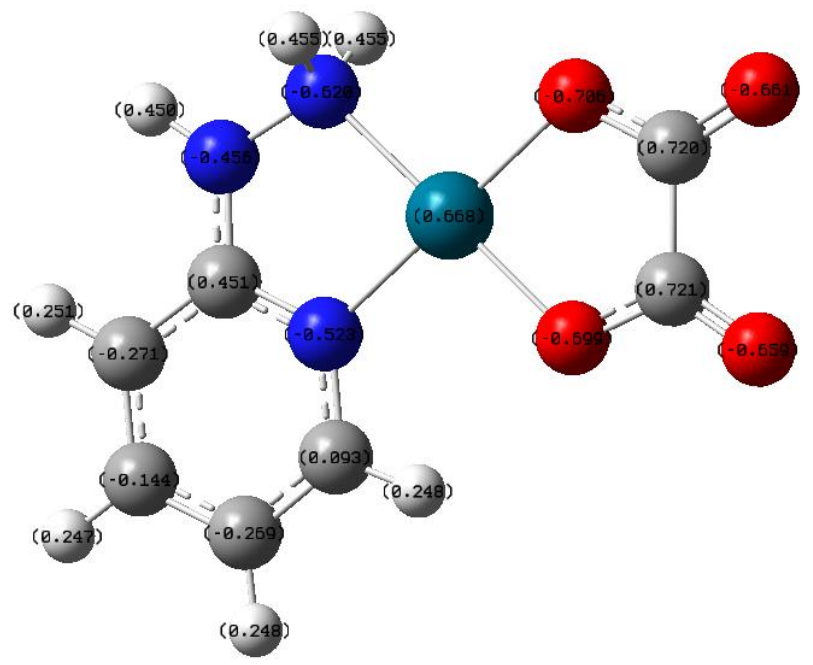

Figure 1. The optimized structure of $[\mathrm{Pd}(\mathrm{hzpy})(\mathrm{ox})]$ complex.

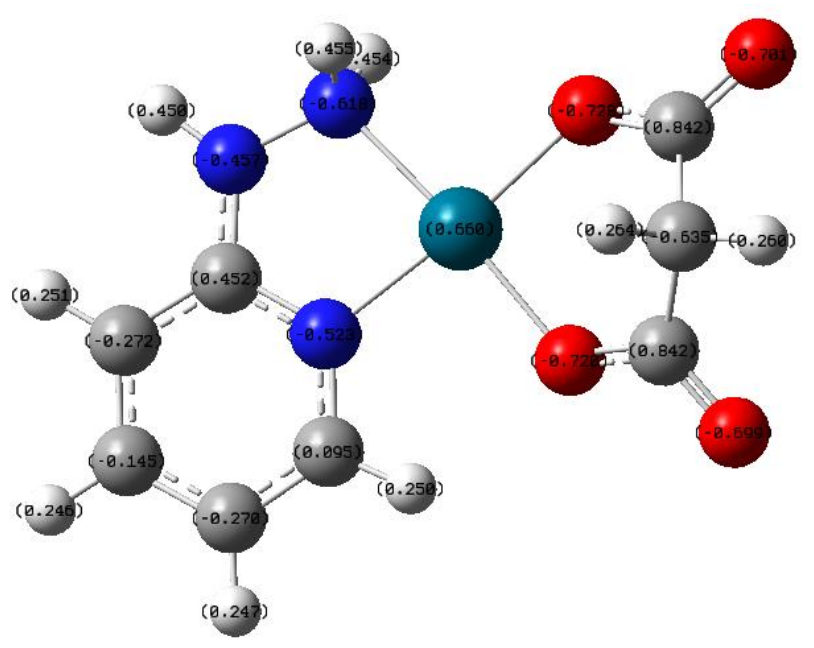

Figure 2. The optimized structure of $[\mathrm{Pd}(\mathrm{hzpy})(\mathrm{ma})]$ complex.

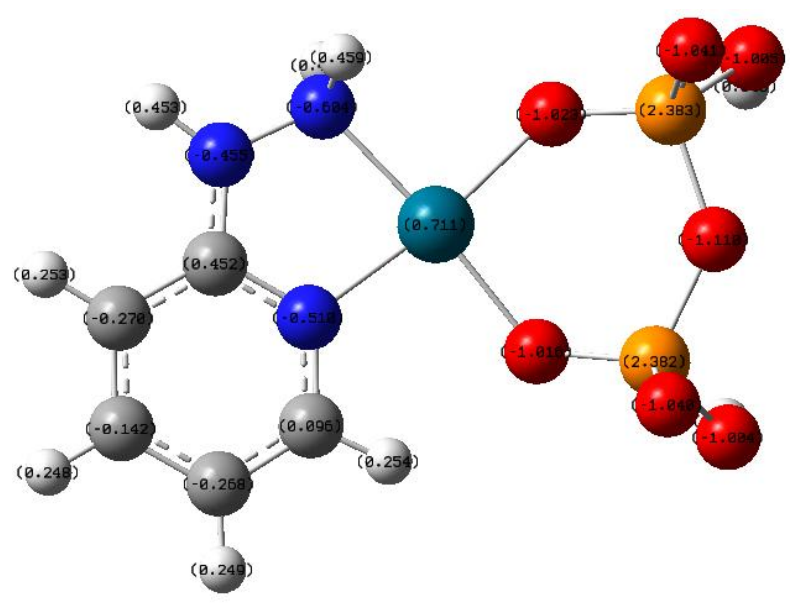

Figure 3. The optimized structure of $[\mathrm{Pd}(\mathrm{hzpy})(\mathrm{pyph})]$ complex. 


\subsection{Evaluation of the antitumor activity}

The cytotoxicity testing was performed according to the method reported in the literature [29,30] at the Regional Centre for Mycology and Biotechnology, Al-Azhar University, Cairo, Egypt. The evaluation of the cytotoxic activities was measured against four human cell lines; MCF-7 cells (breast cancer), HepG-2 cells (Hepatocellular carcinoma), PC3 cells (prostate carcinoma), and HEP-2 (Larynx carcinoma).

\subsection{Synthesis of Palladium (II) Complexes.}

The three complexes' preparation has been carried out by mixing $\mathrm{Na}_{2} \mathrm{PdCl}_{4}$ with ligands (hzpy, ox, ma, and pyph) in a 1:1 molar ratio in two steps (Scheme 1). $1.0 \mathrm{mmol}(0.294 \mathrm{~g})$ of $\mathrm{Na}_{2} \mathrm{PdCl}_{4}$ was mixed with $1.0 \mathrm{mmol}(0.182 \mathrm{~g})$ of 2-hydrazinopyridine in $30 \mathrm{ml}$ ethanol while stirring at room temperature. $1.0 \mathrm{mmol}$ of the secondary ligand $\left(0.126 \mathrm{~g}\right.$ of $\mathrm{H}_{2} \mathrm{C}_{2} \mathrm{O}_{4}, 0.104 \mathrm{~g}$ of $\mathrm{H}_{4} \mathrm{C}_{3} \mathrm{O}_{4}$, and $0.446 \mathrm{~g}$ ) of $\mathrm{Na}_{4} \mathrm{O}_{7} \mathrm{P}_{2} \cdot 10 \mathrm{H}_{2} \mathrm{O}$ ) was then added and the mixture was adjusted to $\mathrm{pH}$ 3.5 and 4 hours. The solid was precipitated and separated by filtration. The filtered complex was washed thoroughly with hot ethanol. Then with diethyl ether, the solid complex was dried under vacuum and subjected to analysis.

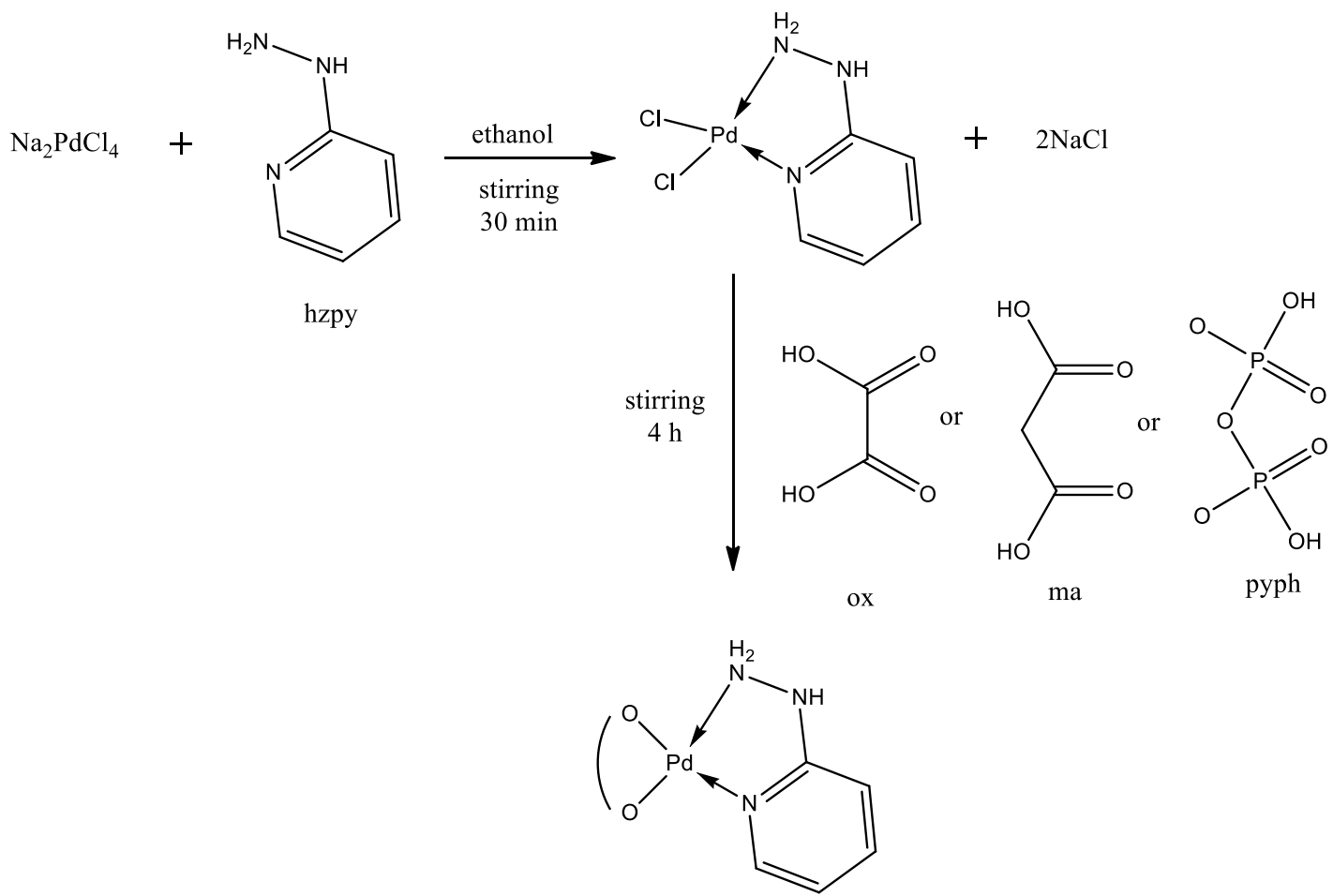

Scheme 1. Preparation of palladium complexes.

[Pd(hzpy)(ox)] complex (1): Yield of $0.236 \mathrm{~g}$ (78\%). Found: C, 27.46; H, 2.35; N, 12.65. Anal. Calc. for $\mathrm{C}_{7} \mathrm{H}_{7} \mathrm{~N}_{3} \mathrm{PdO}_{4}: \mathrm{C}, 27.70 ; \mathrm{H}, 2.32 ; \mathrm{N}, 13.84$. IR $\left(\mathrm{KBr}, \mathrm{cm}^{-1}\right)$ v: 3274 (s), 3159 (s), 1631 (s), 1249 (m), 1188 (s), 763 (s), 532 (w) and 466 (w). ${ }^{1} \mathrm{H}-\mathrm{NMR}$ [ $\delta$, ppm] (DMSO-d6): aromatic protons of hzpy ligand (6.69 - 8.38, m, 3H), N-H and $\mathrm{NH}_{2}$ groups (6.70, m, 3H). FAB-MS: $\mathrm{m} / \mathrm{z}=302\left(\mathrm{M}^{+}-\mathrm{H}\right)$. UV-Vis: 310, 380, 510, 690 and $715 \mathrm{~nm}$.

[Pd(hzpy)(ma)] complex (2): Yield of 0.26 g (82\%). Found: C, 29.45; H, 2.46; N, 12.56. Anal. Calc. for $\mathrm{C}_{8} \mathrm{H}_{9} \mathrm{~N}_{3} \mathrm{O}_{4} \mathrm{Pd}$ : C, 30.25; H, 2.86; N, 13.23. IR ( $\left.\mathrm{KBr}, \mathrm{cm}^{-1}\right)$ v: 3274 (s), 3159 (s),

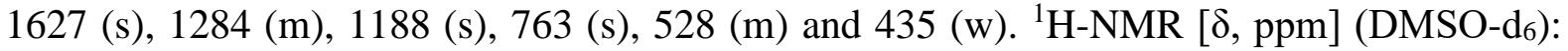
$\mathrm{CH}_{2}$ of malonate ligand $(3.46, \mathrm{~s} 2 \mathrm{H})$, aromatic protons of hzpy ligand $(6.68-8.38, \mathrm{~m}, 3 \mathrm{H}), \mathrm{N}-$ $\mathrm{H}$ and $\mathrm{NH}_{2}$ groups $(6.69, \mathrm{~m}, 3 \mathrm{H})$. FAB-MS: $\mathrm{m} / \mathrm{z}=317\left(\mathrm{M}^{+}\right)$. UV-Vis: 310, 390, 510, 680 and $720 \mathrm{~nm}$. 
[Pd(hzpy)(pyph)] complex (3): Yield of $0.31 \mathrm{~g}$ (80\%). Found: C, 15.56; H, 2.45; N, 11.35. Anal. Calc. for $\mathrm{C}_{5} \mathrm{H}_{9} \mathrm{~N}_{3} \mathrm{P}_{2} \mathrm{Pd}: \mathrm{C}, 15.34 ; \mathrm{H}, 2.32 ; \mathrm{N}, 10.79$. IR $\left(\mathrm{KBr}, \mathrm{cm}^{-1}\right)$ v: $3274(\mathrm{~s})$, 3155 (s), 1249 (w), 1188 (s), 763 (s), 532 (m) and 470 (w). ${ }^{1} \mathrm{H}-\mathrm{NMR}$ [ $\delta$, ppm] (DMSO-d6): aromatic protons of hzpy ligand $(6.68-8.38, \mathrm{~m}, 3 \mathrm{H}), \mathrm{N}-\mathrm{H}$ and $\mathrm{NH}_{2}$ groups $(6.68, \mathrm{~m}, 3 \mathrm{H})$. FABMS: $\mathrm{m} / \mathrm{z}=386\left(\mathrm{M}^{+}-5 \mathrm{H}\right)$. UV-Vis: $310,390,560$ and $720 \mathrm{~nm}$.

\section{Results and Discussion}

\subsection{Characterization of palladium complexes.}

\subsubsection{Infrared spectra.}

The IR spectral data of the complexes are tabulated in Table 1. The N-H stretching peaks of the amino group of hzpy ligand were found at 3305 and $3259 \mathrm{~cm}^{-1}$ in the spectrum of hzpy ligand (Figure S1) have been appeared in the spectrum of the complex as two strong peaks and being shifted to lower frequencies, upon complex formation, at 3274 and $3159 \mathrm{~cm}^{-1}$ indicating the participation of the $\mathrm{NH}_{2}$ group in coordination (Figure 4). There was a shift to higher frequencies in the deformation vibrations as well at $1249 \mathrm{~cm}^{-1}$ ( $\rho \mathrm{t} \mathrm{NH}$ ), $1188 \mathrm{~cm}^{-1}$ $\left(\rho \mathrm{wNH}_{2}\right)$, and $763 \mathrm{~cm}^{-1}\left(\rho \mathrm{NH}_{2}\right)$, also suggesting that the chelation was through the amino group (Table 1). The calculated deformation vibrations appeared at 1280, 1144, and $763 \mathrm{~cm}^{-1}$ with relative errors between -3.7 to $2.5 \%$. The pyridyl ring's involvement in the chelate formation was confirmed by observing the in-plane and out-of-plane ring deformations at 729 and $474 \mathrm{~cm}^{-1}$, respectively [31]. It is worth noting the experimental and theoretical values of the vibrations were close with low relative error percentages (Figures 4, 5, and Table 1). The band due $(v \mathrm{C}=\mathrm{O})$ appeared at $1631 \mathrm{~cm}^{-1}$ and the calculated value 1640 with a relative error of $0.6 \%$. The complex spectrum also showed additional peaks at 532 and $420 \mathrm{~cm}^{-1}$ assigned to $\mathrm{M}-\mathrm{O}$ and M-N bonds, respectively [32, 33].

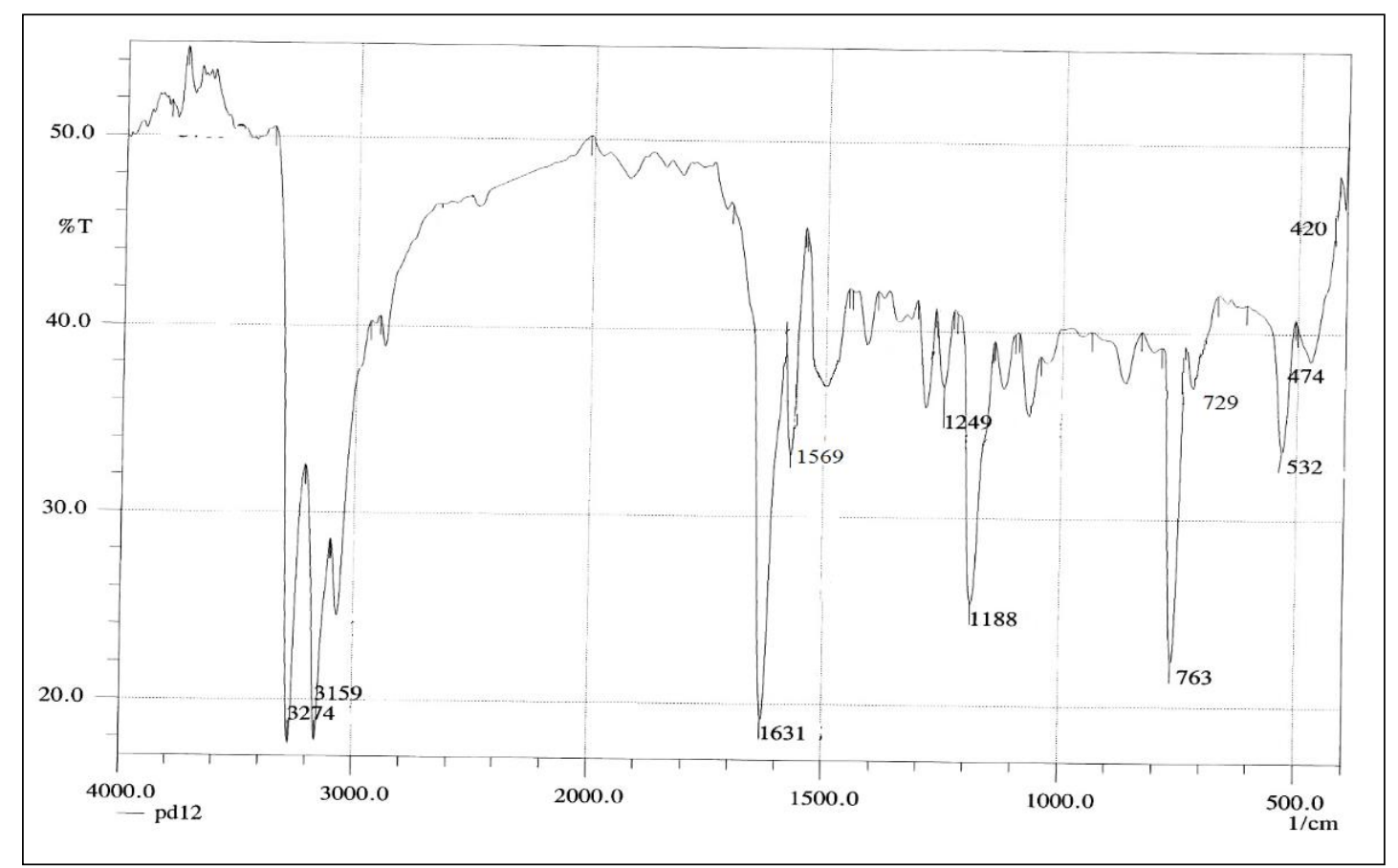

Figure 4. Experimental IR spectrum of [Pd(hzpy)(ox)] complex. 


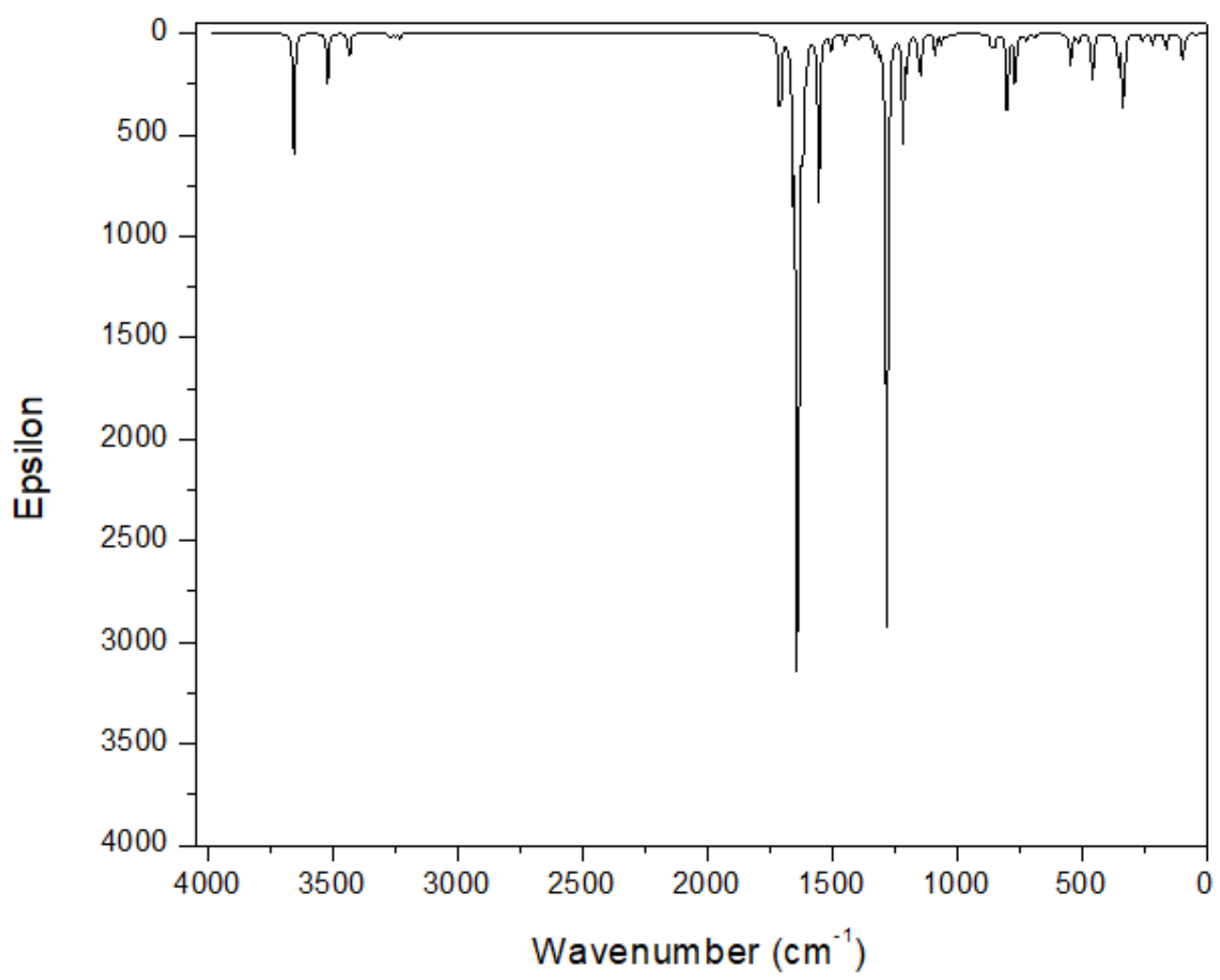

Figure 5. Theoretical IR spectrum of $[\mathrm{Pd}(\mathrm{hzpy})(\mathrm{ox})]$ complex.

The infrared spectrum of $[\operatorname{Pd}($ hzpy)(ma)] complex, Figure 6, displayed a similar pattern as the $[\operatorname{Pd}($ hzpy)(ox)] complex. The chelation was through the amnio group, and the pyridyl ring was confirmed through a shift in the N-H stretching and through the in-plane and out-ofplane ring deformations, respectively.

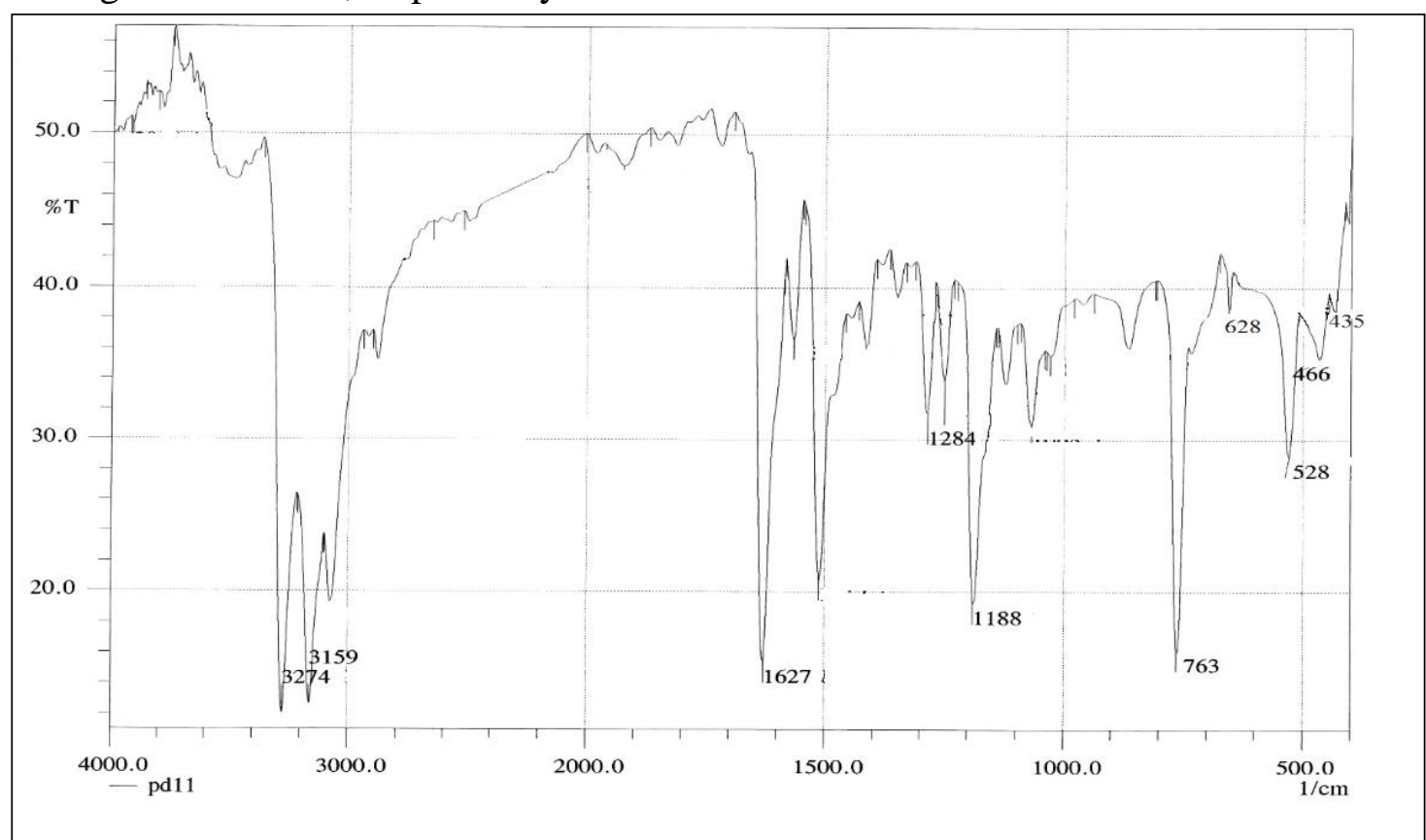

Figure 6. Experimental IR spectrum of $[\operatorname{Pd}($ hzpy)(ma) $]$ complex.

The N-H stretching peaks of the amino group of hzpy were found at 3305 and $3259 \mathrm{~cm}^{-}$ ${ }^{1}$ in the spectrum of hzpy ligand (Figure S1; Supplementary materials) that appeared in the spectrum of the complex as two strong peaks and were shifted to lower frequencies at 3274 and $3159 \mathrm{~cm}^{-1}$. Furthermore, the coordination through the $\mathrm{NH}_{2}$ group was also suggested via 
the higher shift of its deformation vibrations observed at $1284 \mathrm{~cm}^{-1}\left(\rho \mathrm{t} \mathrm{NH}_{2}\right), 1188 \mathrm{~cm}^{-1}$ $\left(\rho \mathrm{wNH}_{2}\right)$, and $763 \mathrm{~cm}^{-1}\left(\rho \mathrm{NH}_{2}\right)$ (Table 1). The calculated deformation vibrations appeared at 1304,1144 , and $720 \mathrm{~cm}^{-1}$ with a relative error between -5.6 to $1.7 \%$. The pyridyl ring's nitrogen was also supported by observing the in-plane and out-of-plane ring deformations at 628 and $466 \mathrm{~cm}^{-1}$, respectively [31]. The calculated error percentages between the theoretical and experimental spectra were relatively low (Figures 6, 7, and Table 1). The band due $(v \mathrm{C}=\mathrm{O})$ appeared at $1627 \mathrm{~cm}^{-1}$ and the calculated value 1600 with a relative error of $-1.7 \%$. The complex spectrum showed additional peaks at 528 and $435 \mathrm{~cm}^{-1}$ assigned to M-O and M-N bonds, respectively [32, 34].

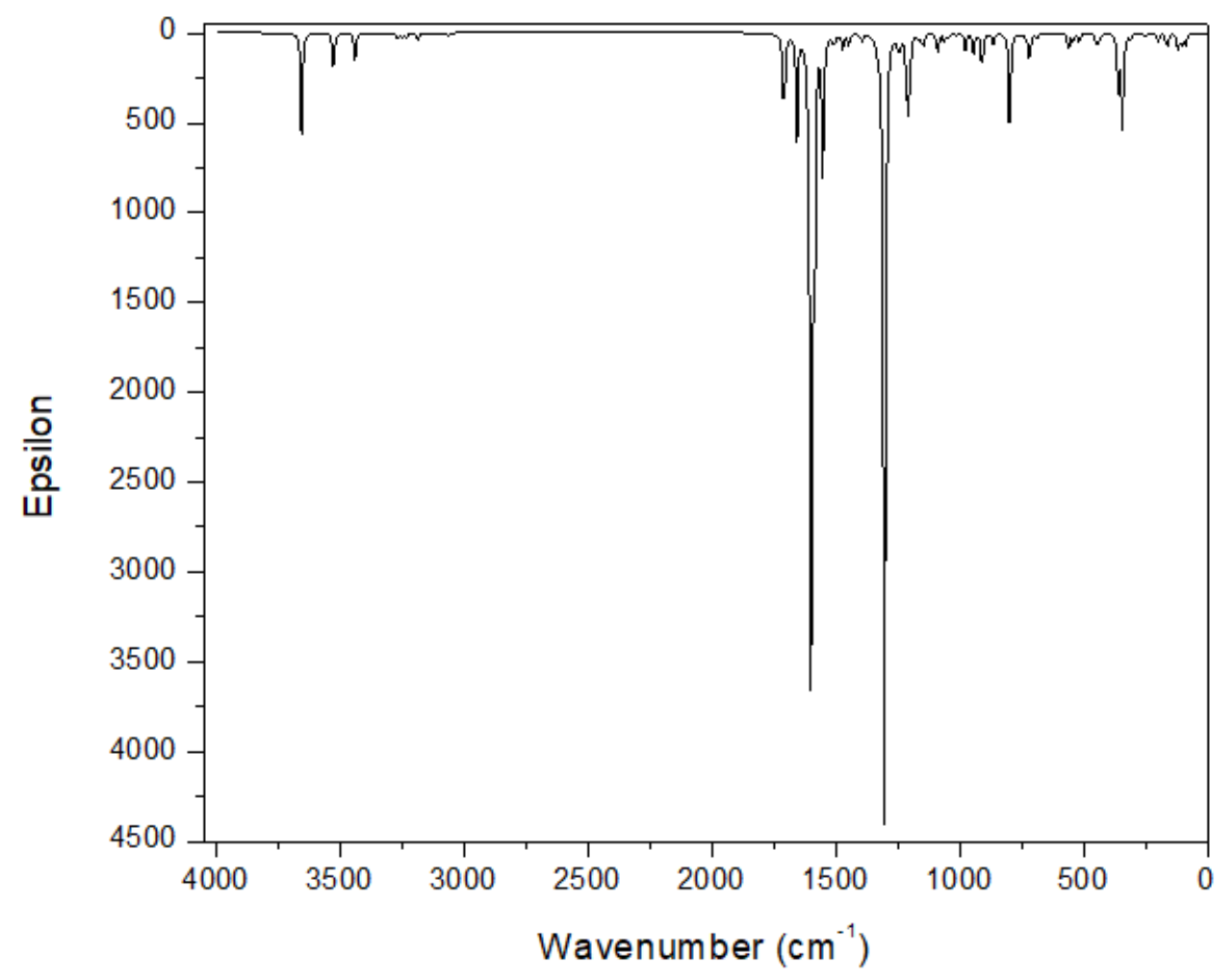

Figure 7. Theoretical IR spectrum of $[\mathrm{Pd}(\mathrm{hzpy})(\mathrm{ma})]$ complex.

The IR spectra of the $[\mathrm{Pd}(\mathrm{hzpy})(\mathrm{pyph})]$ complex are shown in Figure 8. The N-H stretching peaks of the amino group of hzpy (Figure S1) appeared in the complex spectrum as two strong peaks and were shifted to the lower frequency at 3274 and $3155 \mathrm{~cm}^{-1}$, indicating the participation of the $\mathrm{NH}_{2}$ group in coordination. The coordination of the $\mathrm{NH}_{2}$ groups has also been confirmed from the shift of its deformation vibrations ( $\rho \mathrm{tNH}_{2}, \rho w \mathrm{NH}_{2}$, and $\rho \mathrm{NH}_{2}$ ) to higher frequencies at 1249, 1188, and $763 \mathrm{~cm}^{-1}$, respectively (Table 1). The theoretical deformation vibrations appeared at 1304, 11,44 and $720 \mathrm{~cm}^{-1}$, with the relative error between 7.1 to $-2.0 \%$. Generally, the complex's theoretical vibrational spectral data were in good agreement with the corresponding experimental ones (Figure 8, 9, and Table 1). The pyridyl ring's involvement was also supported by the observation of the in-plane and out-of-plane ring deformations at 634 and $470 \mathrm{~cm}^{-1}$, respectively [31]. The band due (vP-O-P) and (vP=O) appeared at $1110 \mathrm{~cm}^{-1}$ and $921 \mathrm{~cm}^{-1}$ in spectrum of the ligand; Figure 8 was found as a small peak, shifted to a lower frequency in the spectrum of the complex at $867 \mathrm{~cm}^{-1}$ indicating the coordination of pyph was through the two oxygen atoms. The complex spectrum also exhibited two peaks at 532 and $470 \mathrm{~cm}^{-1}$ reflected the M-O and M-N bond's vibration, respectively [32, 34]. 


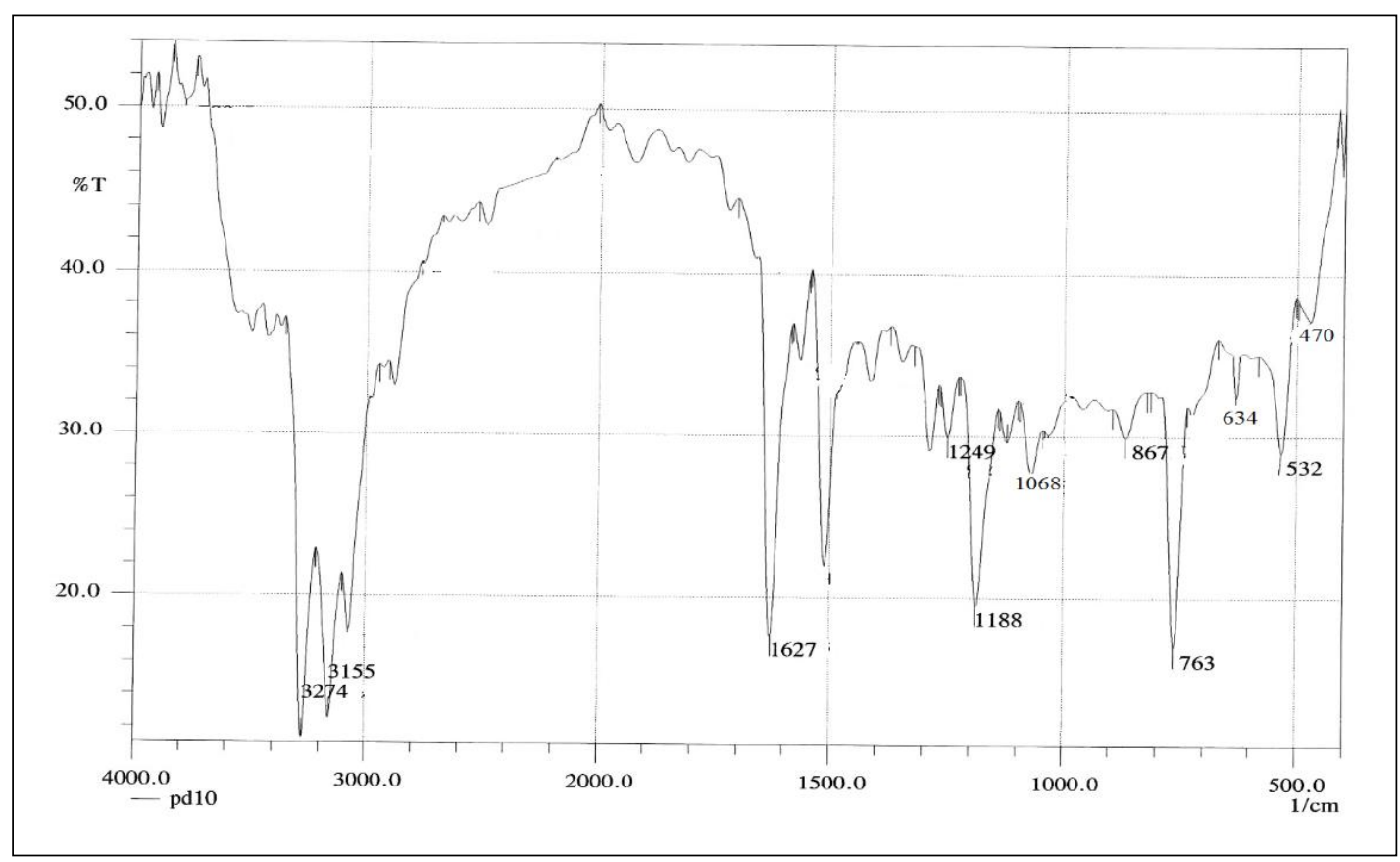

Figure 8. Experimental IR spectrum of [Pd(hzpy)(pyph)] complex.

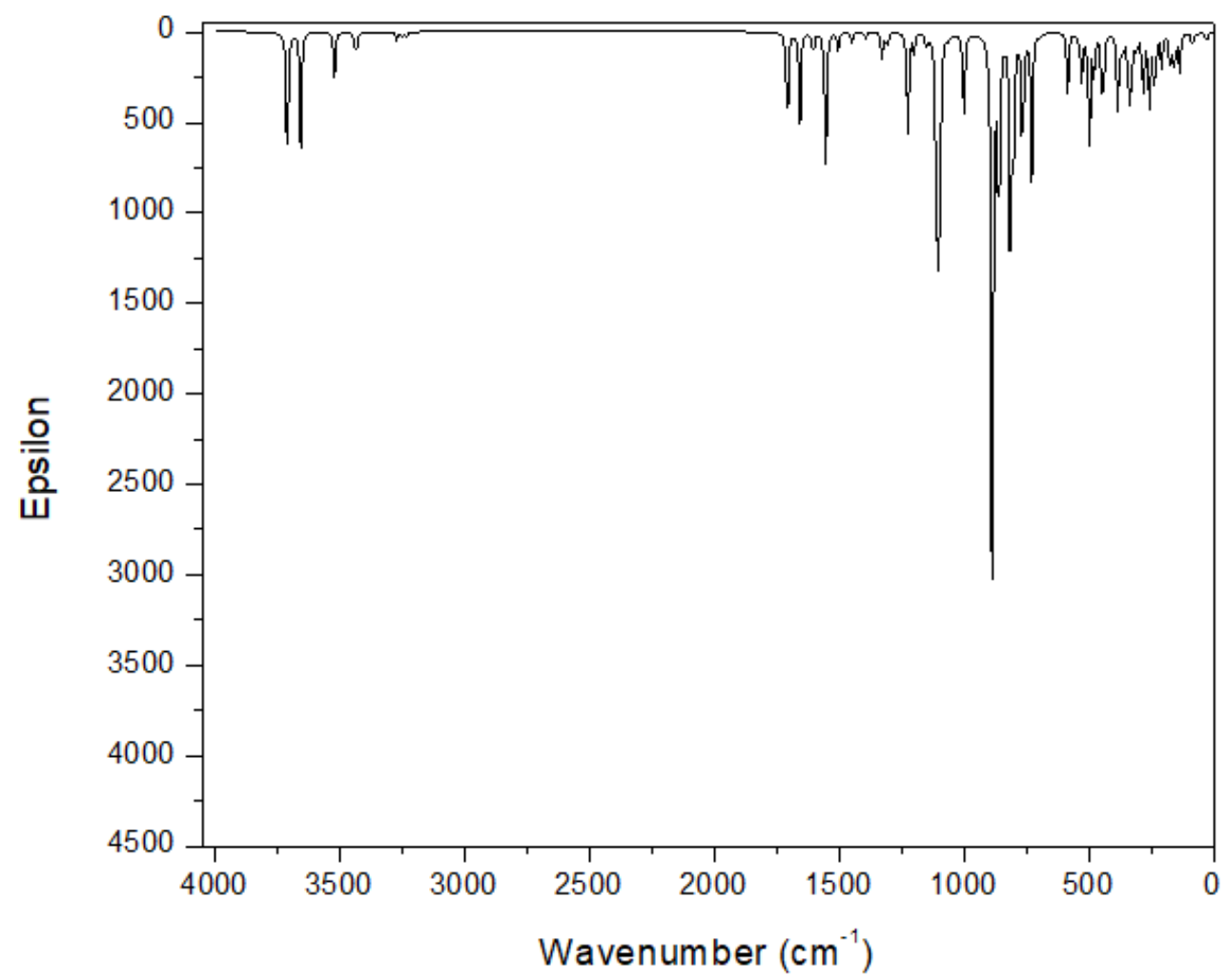

Figure 9. Theoretical IR spectrum of [Pd(hzpy)(pyph)] complex.

Table 1. Characteristic calculated and observed vibrational frequencies $\mathrm{cm}^{-1}$ of the palladium complexes

\begin{tabular}{c|c|c|c|c} 
Complex & Obsd & Calcd & Relative error & Assignment \\
\hline$[\mathrm{Pd}($ hzpy)(ox)] & 3274 & 3520 & 7.5 & $v\left(\mathrm{NH}_{2}\right)$ \\
\hline & 3159 & 3440 & 8.9 & $v\left(\mathrm{NH}_{2}\right)$ \\
\hline & 1631 & 1640 & 0.6 & $v(\mathrm{C}=\mathrm{O})$ \\
\hline & 1249 & 1280 & 2.5 & $\left(\rho \mathrm{NH}_{2}\right)$ \\
\hline & 1188 & 1144 & -3.7 & $\left(\rho \mathrm{NH}_{2}\right)$ \\
\hline & 763 & 768 & 0.7 & $(\rho \mathrm{NH} 2)$ \\
\hline & 532 & 544 & 2.3 & $v(\mathrm{M}-\mathrm{O})$ \\
\hline & 420 & 456 & 8.6 & $v(\mathrm{M}-\mathrm{N})$ \\
\hline$[\mathrm{Pd}($ hzpy)(ma) $]$ & 3274 & 3528 & 7.8 & $v\left(\mathrm{NH}_{2}\right)$ \\
\hline & 3159 & 3440 & 8.9 & $v\left(\mathrm{NH}_{2}\right)$
\end{tabular}




\begin{tabular}{|c|c|c|c|c|}
\hline Complex & Obsd & Calcd & Relative error & Assignment \\
\hline & 1627 & 1600 & -1.7 & $\mathrm{v}(\mathrm{C}=\mathrm{O})$ \\
\hline & 1284 & 1304 & 1.6 & $\left(\rho t \mathrm{NH}_{2}\right)$ \\
\hline & 1188 & 1144 & -3.7 & $\left(\rho w N_{2}\right)$ \\
\hline & 763 & 720 & -5.6 & $\left(\rho \mathrm{NH}_{2}\right)$ \\
\hline & 528 & 560 & 6.1 & $v(\mathrm{M}-\mathrm{O})$ \\
\hline & 435 & 448 & 3.0 & $v(\mathrm{M}-\mathrm{N})$ \\
\hline \multirow[t]{9}{*}{ [Pd(hzpy)(pyph)] } & 3274 & 3520 & 7.5 & $v\left(\mathrm{NH}_{2}\right)$ \\
\hline & 3155 & 3432 & 8.8 & $v\left(\mathrm{NH}_{2}\right)$ \\
\hline & 1249 & 1224 & -2.0 & $\left(\rho t \mathrm{NH}_{2}\right)$ \\
\hline & 1188 & 1104 & -7.1 & $\left(\rho w N_{2}\right)$ \\
\hline & 1110 & 1104 & -0.5 & (vP-O-P) \\
\hline & 921 & 912 & -1.0 & $(v \mathrm{P}=\mathrm{O})$ \\
\hline & 763 & 728 & -4.6 & $\left(\operatorname{prNH}_{2}\right)$ \\
\hline & 532 & 504 & -5.3 & $v(\mathrm{M}-\mathrm{O})$ \\
\hline & 470 & 448 & -4.7 & $v(\mathrm{M}-\mathrm{N})$ \\
\hline
\end{tabular}

\subsection{2. ${ }^{1} \mathrm{HNMR}$ spectra.}

The NMR spectra confirmed the diamagnetic properties of the three palladium complexes. In the case of $[\operatorname{Pd}(\mathrm{hzpy})(\mathrm{ox})]$ complex, the aromatic protons of hzpy ligand were observed as a multiplet at $(6.69-8.38, \mathrm{~m}, 3 \mathrm{H})$ in addition to the protons of the $\mathrm{N}-\mathrm{H}$ and $\mathrm{NH}_{2}$ groups which were appeared at $(6.70, \mathrm{~m}, 3 \mathrm{H})$. The same peaks appeared almost at the same chemical shifts for [Pd(hzpy)(pyph)] complex; aromatic protons of hzpy ligand (6.68 - 8.38, $\mathrm{m}, 3 \mathrm{H}), \mathrm{N}-\mathrm{H}$, and $\mathrm{NH}_{2}$ groups $(6.68, \mathrm{~m}, 3 \mathrm{H})$. [Pd(hzpy)(ma)] complex exhibited the same peaks in the same regions; aromatic protons of hzpy ligand $(6.68-8.38, \mathrm{~m}, 3 \mathrm{H}), \mathrm{N}-\mathrm{H}$, and $\mathrm{NH}_{2}$ groups $(6.69, \mathrm{~m}, 3 \mathrm{H})$ in addition to the methylene group of the malonate ligand which appeared as a singlet at $(3.46, \mathrm{~s}, 2 \mathrm{H})$.

\subsubsection{Mass spectra.}

The mass spectral data of the three palladium complexes are summarized in Table 2. The mass spectrum of $[\mathrm{Pd}(\mathrm{hzpy})(\mathrm{ox})]$ complex (M. wt. = 303.57) displayed the parent peak at $\mathrm{m} / \mathrm{z}=302\left(\mathrm{M}^{+}-\mathrm{H}\right)$ in addition to a peak at $\mathrm{m} / \mathrm{z}=110$ that is assigned to (hzpy) ligand and a peak at $\mathrm{m} / \mathrm{z}=140$ assigned to $\left(\mathrm{PdO}_{2}\right)$ compound. The mass spectrum of [Pd(hzpy)(ma)] complex (M. wt. $=317.59)$ showed a peak at $\mathrm{m} / \mathrm{z}=317$ assigned to the parent peak $\left(\mathrm{M}^{+}\right)$. The spectrum showed two peaks at $\mathrm{m} / \mathrm{z}=109$ and at $\mathrm{m} / \mathrm{z}=150$, which corresponded to hzpy ligand and $\mathrm{PdCO}_{2}$. The mass spectrum of $[\mathrm{Pd}(\mathrm{hzpy})(\mathrm{pyph})]$ complex $(\mathrm{M}$. wt. = 391.51) gave a parent peak at $\mathrm{m} / \mathrm{z}$ $=386\left(\mathrm{M}^{+}-5 \mathrm{H}^{+}\right)$, peak at $\mathrm{m} / \mathrm{z}=109$ assigned to (hzpy) and peak at $\mathrm{m} / \mathrm{z}=156$ assigned to $\left(\mathrm{P}_{2} \mathrm{O}_{5}\right)$. The palladium oxide $(\mathrm{PdO})$ appeared in the three palladium spectra at $\mathrm{m} / \mathrm{z}=122$.

Table 2. Important mass data of palladium complexes.

\begin{tabular}{l|c|l} 
Complex & Molar mass & \multicolumn{1}{|c}{$\mathbf{m} / \mathbf{z}$ Values } \\
\hline$[\operatorname{Pd}($ hzpy)(ox) $]$ & 303.57 & $302,301,215,140,134,109,108,106,104$. \\
\hline$[\operatorname{Pd}($ hzpy)(ma) $]$ & 317.59 & $317,312,231,150,125,118,117,109,105,104$ \\
\hline$[\operatorname{Pd}($ hzpy)(pyph) & 391.51 & $386,231,175,156,126,119,110,109,104,94$
\end{tabular}

\subsubsection{UV-Vis spectra.}

The three complexes' UV-Vis spectra were recorded in the visible region, and the electronic transition and their assignments are listed in Table 3. The absorption spectrum of $[\mathrm{Pd}($ hzpy)(ox)] complex (Figure 10) displayed a broadband in 280-350 $\mathrm{nm}$ region with maxima at $310 \mathrm{~nm}$, which was assigned to the $\pi-\pi^{*}$ transition within the hzpy ligand. The $\mathrm{n}-\pi^{*}$ transition overlapped with MLCT. Both appeared as a shoulder at $380 \mathrm{~nm}[35,36]$. The $d-d$ transitions expected for square planar geometry were observed at 510, 690, and $715 \mathrm{~nm}$, which may be 
assigned to ${ }^{1} \mathrm{~A}_{1 \mathrm{~g}} \rightarrow{ }^{1} \mathrm{Eg}_{\mathrm{g}},{ }^{1} \mathrm{~A}_{1 \mathrm{~g}} \rightarrow{ }^{1} \mathrm{~A}_{2 \mathrm{~g}}$ and ${ }^{1} \mathrm{~A}_{1 \mathrm{~g}} \rightarrow{ }^{3} \mathrm{~A}_{2 \mathrm{~g}}$; respectively [37]. The same pattern was also observed in the other two complexes; $[\mathrm{Pd}(\mathrm{hzpy})(\mathrm{ma})]$ and [Pd(hzpy)(pyph)]. The intra-ligand transitions within the hzpy ligand were in the same region 280-350 $\mathrm{nm}$ range with maxima at $310 \mathrm{~nm}$. MLCT transitions appeared as a shoulder at $390 \mathrm{~nm}$ that was overlapped with $\mathrm{n}-\pi^{*}$ electronic transition in two spectra. [35, 36] The $d$ - $d$ transitions in the case of [Pd(hzpy)(ma)] complex appeared between 510 - $720 \mathrm{~nm}$ (Figure 11) and between $560-720 \mathrm{~nm}$ for [Pd(hzpy)(pyph)] complex (Figure 12) [37].

Table 3. The calculated electronic excitations based on TD-DFT/B3LYP/SDD method and the corresponding

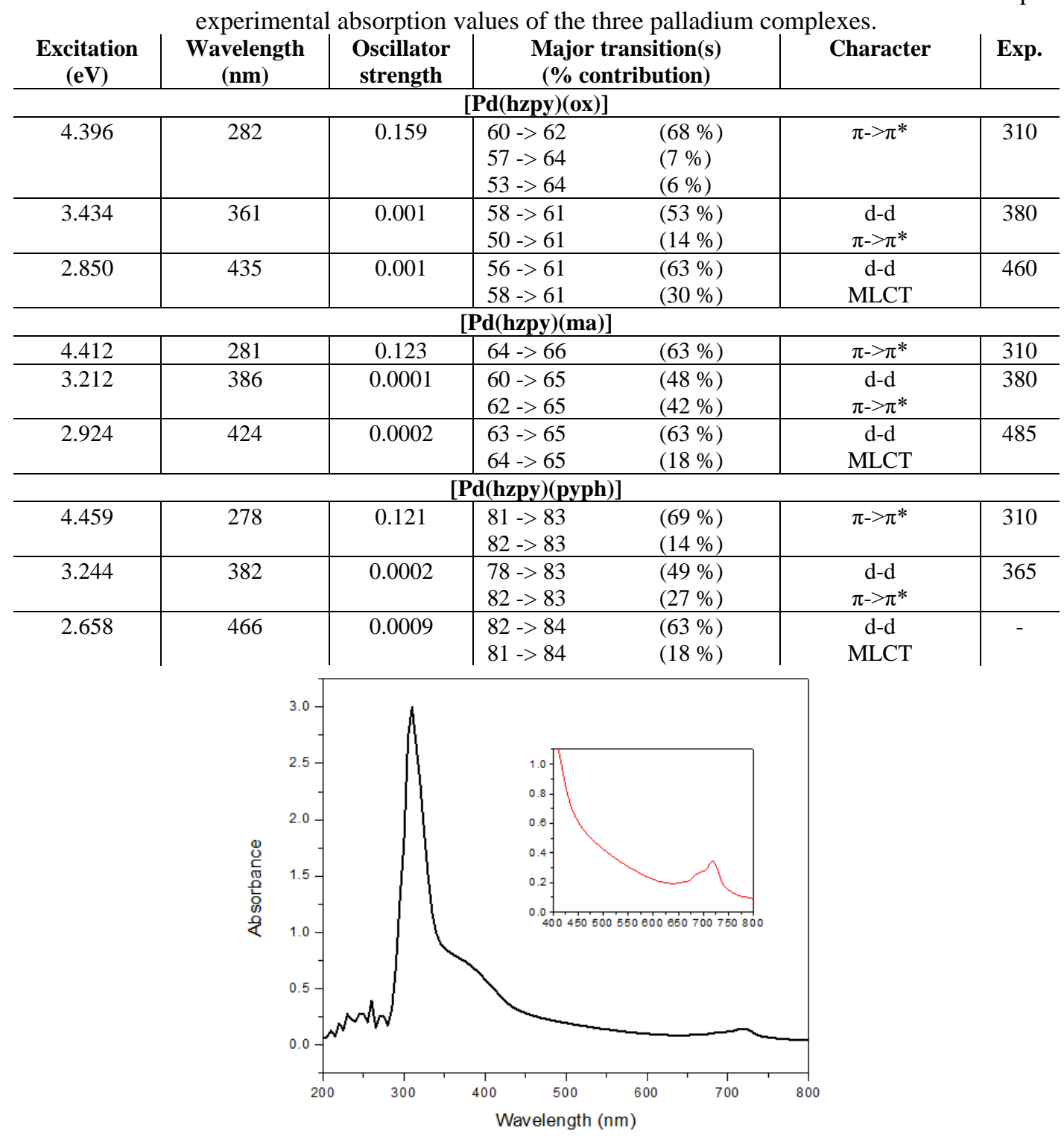

Figure 10. Experimental UV-Vis spectrum of $[\operatorname{Pd}($ hzpy)(ox)] complex.

\subsubsection{Magnetic properties.}

Magnetic susceptibility measurements also confirmed the diamagnetic nature of the three palladium complexes. Therefore, the three complexes have square planner geometry, and the $\mathrm{Pd}(\mathrm{II})$ metal ion center has $d^{8}$ configuration $\mathrm{eg}_{\mathrm{g}} \mathrm{a}_{1 \mathrm{~g}}{ }^{2} \mathrm{~b}_{2 \mathrm{~g}}{ }^{2}$. Based on different analysis techniques (spectral and magnetic), the hzpy coordinated via the amino group and the pyridyl ring's nitrogen atom. Oxalate, malonate, and pyrophosphate act as bidentate through their oxygen atoms. 


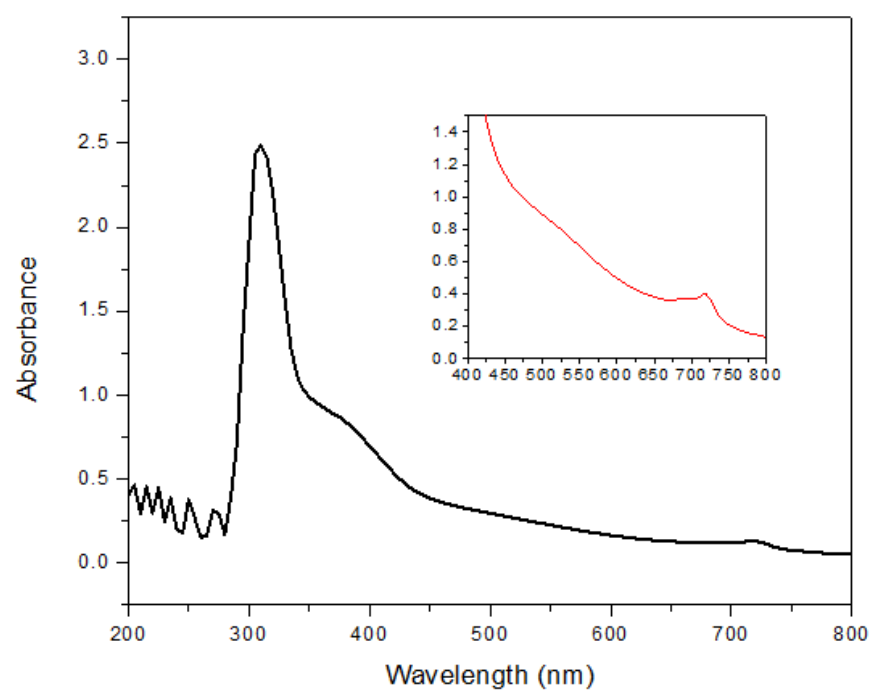

Figure 11. Experimental UV-Vis spectrum of $[\mathrm{Pd}(\mathrm{hzpy})(\mathrm{ma})]$ complex.

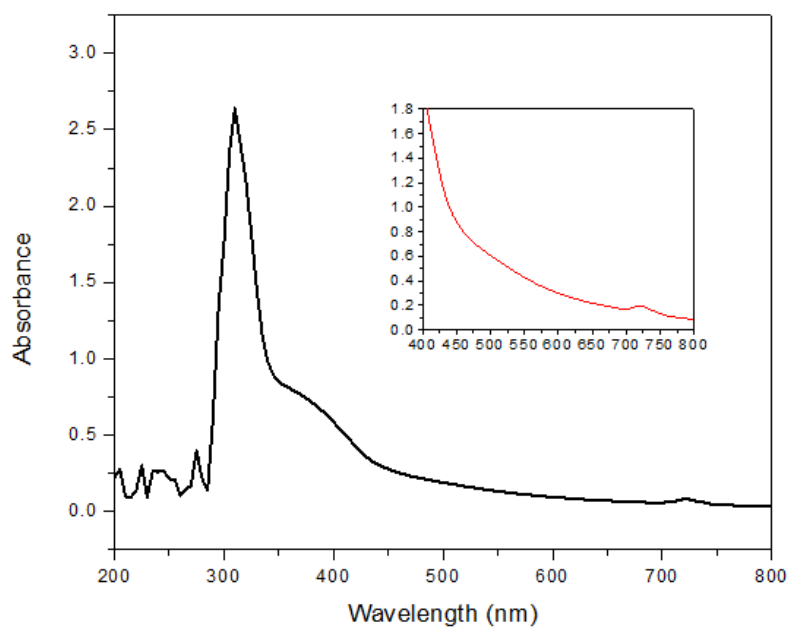

Figure 12. Experimental UV-Vis spectrum of $[\mathrm{Pd}(\mathrm{hzpy})(\mathrm{pyph})]$ complex.

\subsubsection{Thermal analysis.}

The three palladium complexes' thermal properties were investigated through TGA and DTG plots (Figure S2-S4; Supplementary materials).). The temperatures of decomposition and the corresponding mass losses of species are given in (Table 4). The thermal decomposition steps of each complex are shown in Schemes 2 - 4. TGA and DTG plots (Figure S2; Supplementary materials).) of [Pd(hzpy)(ox)] complex showed that the complex decomposed through two steps; Scheme 2. The first step was between $451-680 \mathrm{~K}$ and reflected the loss of $54.3 \%$ of the sample $(54.4 \%$ calc.), such loss assigned to the elimination of hzpy ligand $\left(\mathrm{C}_{5} \mathrm{H}_{3} \mathrm{~N}_{3}\right)$ and $2 \mathrm{CO}$ species (mass $\left.=165 ; \mathrm{m} / \mathrm{z}=140\right)$.

Table 4. Thermo Analytical data of palladium complex.

\begin{tabular}{l|c|c|c|c|c} 
Complexes & $\begin{array}{c}\text { TG range } \\
(\mathbf{K})\end{array}$ & $\begin{array}{c}\text { DTAmax } \\
(\mathbf{K})\end{array}$ & $\begin{array}{c}\text { Mass loss found } \\
\text { (calcd. \%) }\end{array}$ & $\begin{array}{c}\text { Assignment of the } \\
\text { removed species }\end{array}$ & $\begin{array}{c}\text { Metallic residue } \\
\text { found (cal.\%) }\end{array}$ \\
\hline$[\mathrm{Pd}(\mathrm{hzpy})(\mathrm{ox})]$ & $471-780$ & 483 & $54.3,(54.4)$ & $\mathrm{C}_{5} \mathrm{H}_{7} \mathrm{~N}_{3}, 2 \mathrm{CO}$ & $\mathrm{PdO}$ \\
& $1102-1175$ & 1120 & $5.2,(5.1)$ & $1 / 2 \mathrm{O}_{2}$ & $40.5 ;(40.2)$ \\
\hline$[\mathrm{Pd}(\mathrm{hzpy})(\mathrm{ma})]$ & $464-754$ & 473 & $52.7 ;(52.6)$ & $\mathrm{C}_{5} \mathrm{H}_{9} \mathrm{~N}_{3}, 2 \mathrm{CO}$ & $\mathrm{PdO}$ \\
& $1076-1177$ & 1156 & $8.01 ;(8.8)$ & $\mathrm{CO}$ & $38.5 ;(38.4)$ \\
\hline$[\mathrm{Pd}(\mathrm{hzpy})($ pyph) $]$ & $431-531$ & 478 & $30.07 ;(32.6)$ & $\mathrm{C}_{5} \mathrm{H}_{7} \mathrm{~N}_{3}, \mathrm{H}_{2} \mathrm{O}$ & $\mathrm{PdO}$ \\
& $531-1213$ & 1156 & $37.3 ;(36.5)$ & $\mathrm{P}_{2} \mathrm{O}_{5}$ & $30.1 ;(31.3)$
\end{tabular}


The second one $(1102-1175 \mathrm{~K})$ was due to the loss of $5.2 \%$ (5.1\% calc.) could be attributed to the loss of $1 / 2 \mathrm{O}_{2}$ species. The palladium oxide $(\mathrm{PdO})$ (mass $\left.=122\right) 40.5 \%$, was the residue at the end of the analysis $(40.2 \%$ calc $)$.

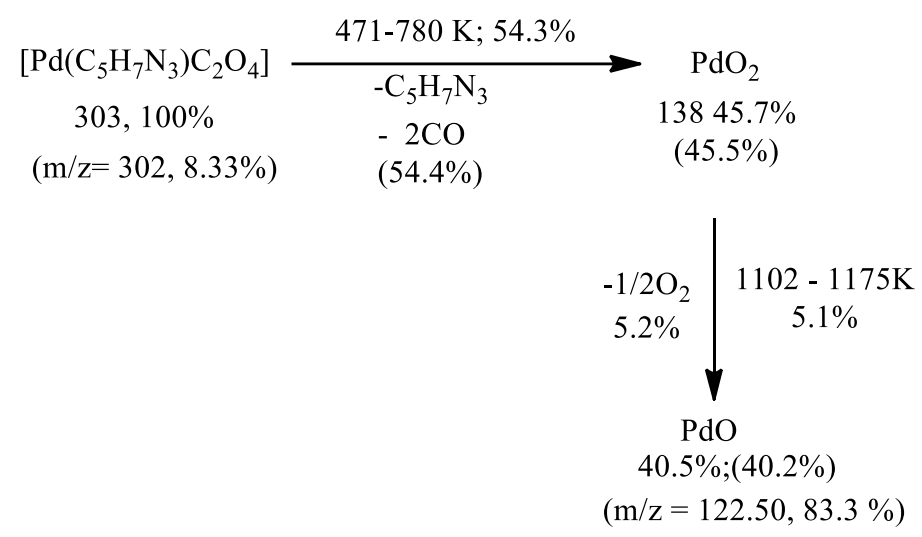

Scheme 2. Thermal decomposition of [Pd(hzpy)(ox)] complex.

The thermal analysis of the [Pd(hzpy)ma] complex (Figure S3; Supplementary materials) involves two decomposition steps, Scheme 3, at $464-753$ and $1176-1177 \mathrm{~K}$. The decomposition also started with the removal of (hzpy) $\mathrm{C}_{5} \mathrm{H}_{7} \mathrm{~N}_{3}$ in addition to $2 \mathrm{CO}$ species (mass $=165 ; \mathrm{m} / \mathrm{z}=167.2)$. The second decomposition step was due to the removal of $8.01 \%(8.8 \%$ calc.), which may be attributed to the loss of CO. Palladium oxide $\mathrm{PdO}$ (mass $=122 ; \mathrm{m} / \mathrm{z}=$ 122.6) was the only residue at the end of the analysis; $38.5 \%$, (38.4\% calc.).

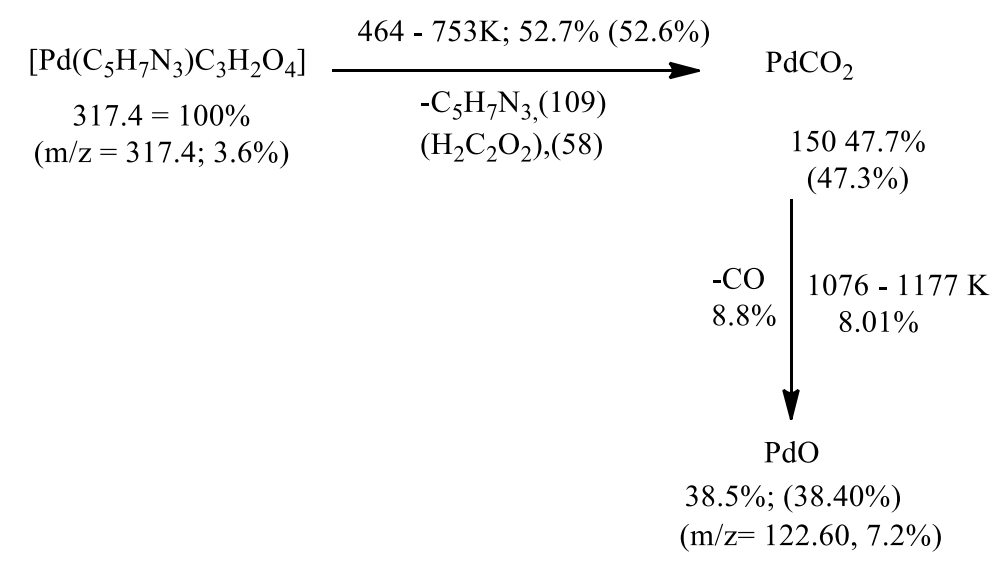

Scheme 3. Thermal decomposition of $[\operatorname{Pd}(\mathrm{hzpy})(\mathrm{ma})]$ complex.

TGA plot (Figure S4; Supplementary materials) of [Pd(hzpy)pyph] complex showed that the decomposition included two steps; Scheme 4. The first decomposition step (431-531 $\mathrm{K}$ ), resulted from removing the hzpy and water groups $30.07 \%$ (32.6\% calc.). The second one, the weight loss, was $37.3 \%$ of the sample ( $36.5 \%$ calc.) due to the loss of $\mathrm{P}_{2} \mathrm{O}_{5}$ compound (mass $=142 ; \mathrm{m} / \mathrm{z}=142.7) . \mathrm{PdO} 30.1 \%$, (31.3\% calc) was the oxide residue (mass=122; $\mathrm{m} / \mathrm{z}=125.2$ ). The thermodynamic parameters of the decomposition peaks were calculated using Horowitz-Metzger and Coats-Redfern equations [38-43]. The correlation coefficients of the Arrhenius plots of the three complexes' thermal decomposition steps were found to range from $0.81-0.97$, indicating good fitness of the linear function. Table 5 gives the decomposition temperature ranges, DTG peak temperature, correlation coefficients of the Arrhenius plots, and the thermodynamic parameters. The complexes showed considerable thermal stability, which is reflected from the overall activation energy sum to 678,981 , and $633 \mathrm{~kJ} \mathrm{~mol}^{-1}$ for $[\operatorname{Pd}($ hzpy $)(\mathrm{ox})] \cdot[\operatorname{Pd}(\mathrm{hzpy})(\mathrm{ma})]$ and $[\mathrm{Pd}(\mathrm{hzpy})(\mathrm{pyph})]$, respectively compared to that of 
$\left[\mathrm{Pd}(\mathrm{hzpy}) \mathrm{Cl}_{2}\right]$, which has an overall activation energy of $580 \mathrm{KJ} \mathrm{mol}^{-1}$, reflecting that the former complexes have two chelating agents instead of one as in the latter complex.

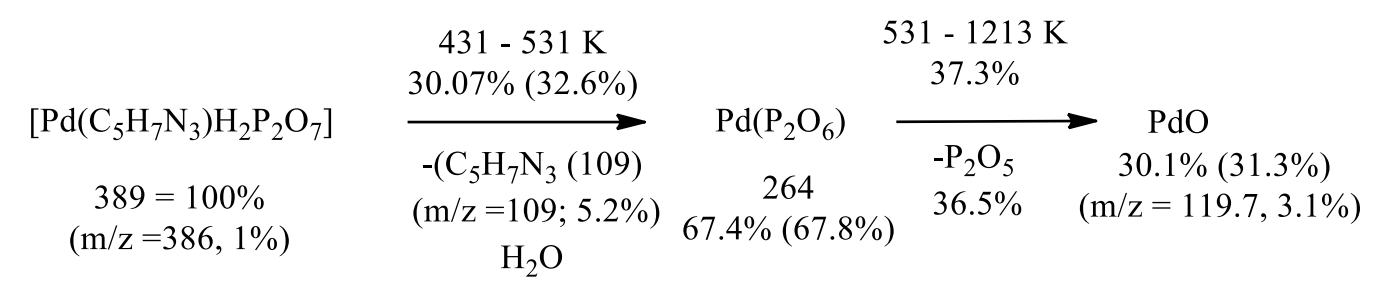

Scheme 4. Thermal decomposition of $[\mathrm{Pd}(\mathrm{hzpy})(\mathrm{pyph})]$ complex.

Table 5. Thermodynamic data of the palladium complexes.

\begin{tabular}{|c|c|c|c|c|c|c|}
\hline Complex & $\begin{array}{c}\text { Decomposition } \\
\text { temperature (K) }\end{array}$ & $\begin{array}{c}\Delta \mathbf{E} \\
\mathbf{K} \mathbf{J ~ m o l}^{-1}\end{array}$ & $\mathbf{R}^{2}$ & $\begin{array}{c}\Delta S \\
\mathbf{J ~ K ~ K}^{-1} \mathbf{m o l}^{-1}\end{array}$ & $\begin{array}{c}\Delta \mathbf{H} \\
\mathbf{K} \mathbf{J ~ m o l}^{-1}\end{array}$ & $\begin{array}{c}\Delta \mathbf{G} \\
\mathbf{K} \mathbf{J ~ m o l}^{-1}\end{array}$ \\
\hline \multirow[t]{3}{*}{$\operatorname{Pd}($ hzpy)(ox)] } & \multirow{3}{*}{$\begin{array}{c}464-753 \\
1076-1177\end{array}$} & 50 & \multirow{3}{*}{$\begin{array}{l}0.81 \\
0.97\end{array}$} & -177 & 46 & 139 \\
\hline & & 628 & & 287 & 618 & 291 \\
\hline & & 678 & & 110 & 664 & 430 \\
\hline \multirow[t]{3}{*}{$\operatorname{Pd}($ hzpy)(ma)] } & \multirow{3}{*}{$\begin{array}{c}464-753 \\
1076-1177\end{array}$} & 42 & \multirow{3}{*}{$\begin{array}{l}0.81 \\
0.96\end{array}$} & -192 & 38 & 138 \\
\hline & & 939 & & 558 & 929 & 292 \\
\hline & & 981 & & 366 & 967 & 430 \\
\hline \multirow[t]{3}{*}{ [Pd(hzpy)(pyph)] } & \multirow{3}{*}{$\begin{array}{c}394-822 \\
1080-1213\end{array}$} & 49 & \multirow{3}{*}{$\begin{array}{l}0.90 \\
0.96\end{array}$} & -181 & 44 & 140 \\
\hline & & 584 & & 238 & 574 & 299 \\
\hline & & 633 & & 57 & 618 & 439 \\
\hline
\end{tabular}

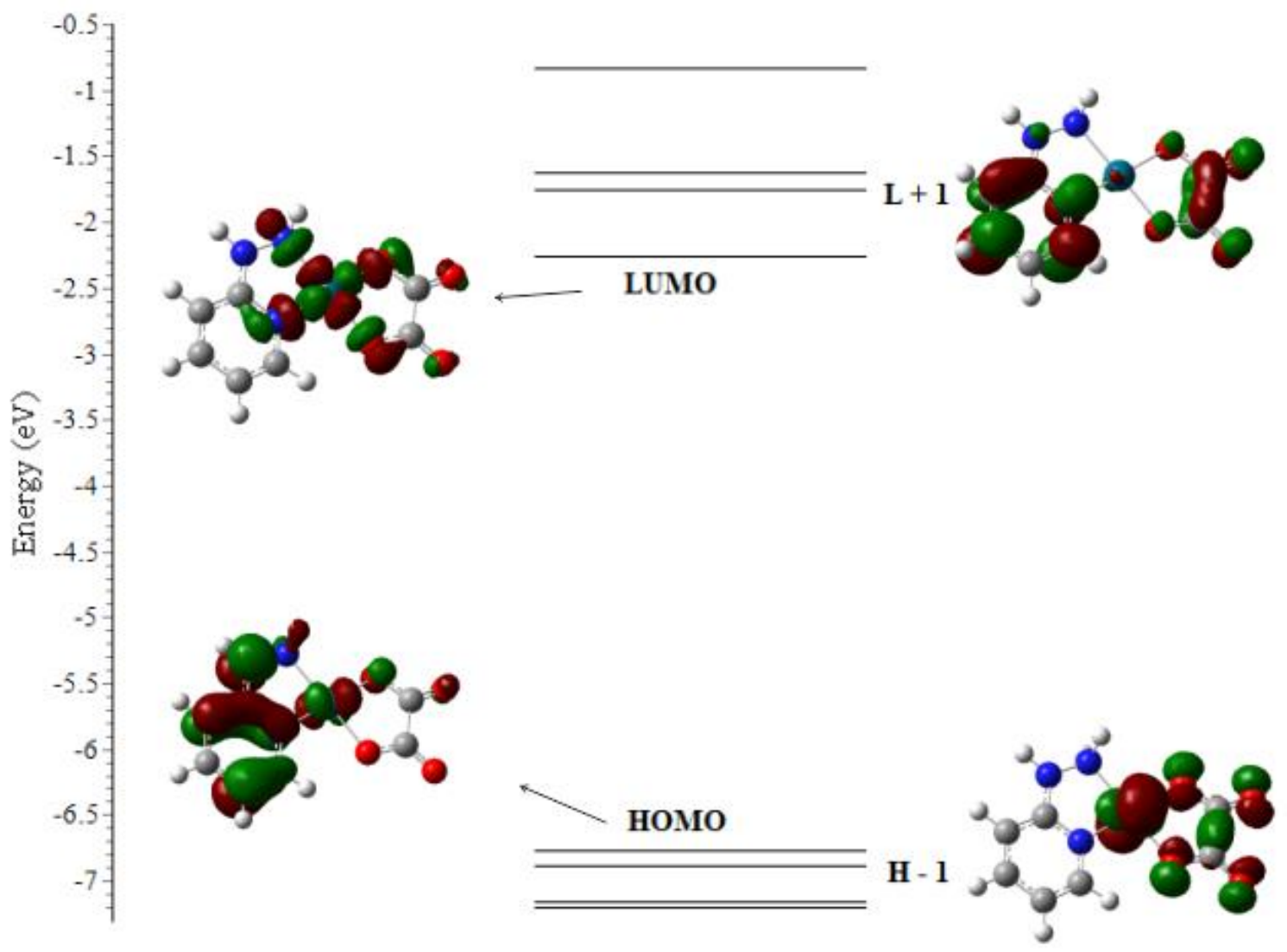

Figure 13. The energy (eV), character, and some contours of the molecular orbitals of [Pd(hzpy)(ox)] complex.

\subsection{Theoretical studies.}

The optimized geometries of the complexes are given in Figures $1-3$. Bond lengths and angles surrounding the central palladium ion are reported in Tables S1 - S3; Suplementary materials). The Pd-N and Pd-O bond lengths are within the regular range reported in the literature [16, 44]. TD-DFT investigations calculations were made to study the electronic transitions. Frequency calculations were performed for the optimized geometries. Different 
quantum parameters were calculated (frontier energy levels, softness, hardness, electronegativity, chemical potential, and electronic charge) to study the palladium complexes' stability (Table 6) [45-50]. The HOMO - LUMO diagrams of the palladium complexes are shown in Figures 13 - 15, and the energy gaps of [Pd(CPDA)(ox)], [Pd(CPDA)(ma)] and $[\operatorname{Pd}(\mathrm{CPDA})(\mathrm{pyph})]$ are equal to $4.51,4.57$ and $4.16 \mathrm{eV}$, respectively; these energy gaps indicate that the two complexes are stable transition metal complexes [51].

Table 6. Calculated quantum parameters.

\begin{tabular}{l|c|c|c|c|c|c|c|c|c} 
Complex & HOMO & LUMO & $\mathbf{x}$ & $\boldsymbol{\eta}$ & $\boldsymbol{\sigma}$ & $\mathbf{p i}$ & $\boldsymbol{\Delta} \mathbf{E}$ & $\boldsymbol{\omega}$ & $\boldsymbol{\Delta N}_{\max }$ \\
\hline$[\operatorname{Pd}($ hzpy)(ox) $]$ & -6.77 & -2.25 & 4.51 & 2.25 & 0.44 & -4.51 & 4.51 & 4.51 & 1.99 \\
\hline$[\operatorname{Pd}($ hzpy)(ma) $]$ & -6.7 & -2.15 & 4.43 & 2.28 & 0.43 & -4.43 & 4.57 & 4.30 & 1.94 \\
\hline$[\operatorname{Pd}($ hzpy)(pyph) $]$ & -6.85 & -2.69 & 4.77 & 2.08 & 0.48 & -4.77 & 4.16 & 5.47 & 2.29
\end{tabular}

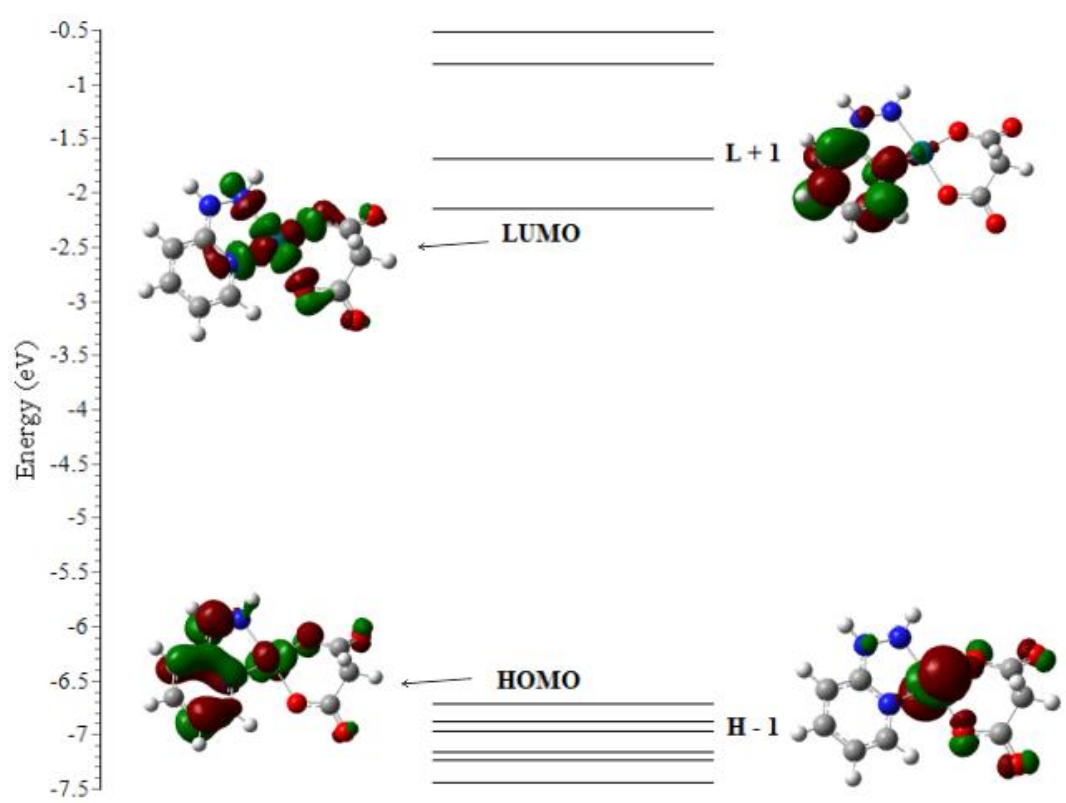

Figure 14. The energy (eV), character, and some contours of the molecular orbitals of $[\mathrm{Pd}(\mathrm{hzpy})(\mathrm{ma})]$ complex.

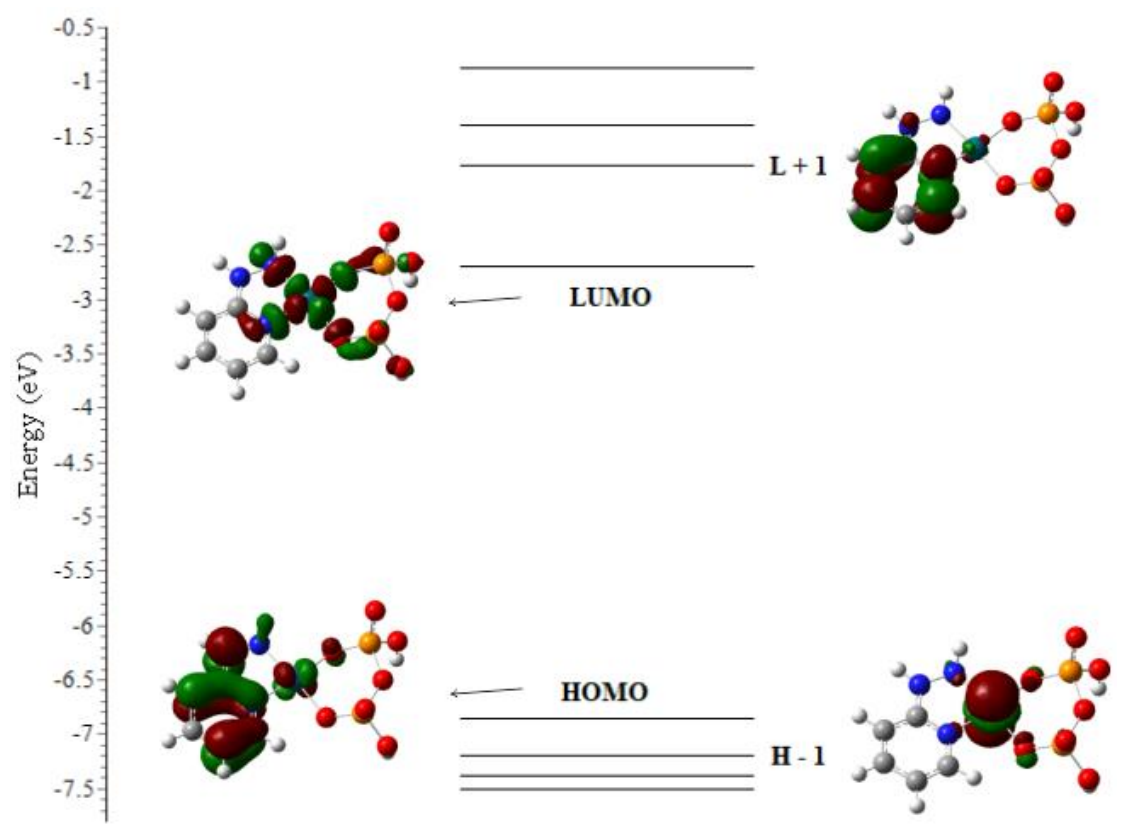

Figure 15. The energy (eV), character, and some contours of the molecular orbitals of [Pd(hzpy)(pyph)] complex. 
The three palladium complexes' UV-Vis spectra were studied, and the corresponding electronic transitions were investigated using TDDFT based on the optimized singlet state geometry (square planar) using SDD basis set (Figures S4 - S7; Supplementary materials). In $[\mathrm{Pd}$ (hzpy)(ox)] complex, HOMO orbital is localized mainly on $\pi$ orbitals of hzpy ligand (75 $\%$ ) in addition to $18 \%$ from $d$-orbital of $\mathrm{Pd}(\mathrm{II})$ while $\mathrm{H}-1$ orbital consists of d-orbital of $\mathrm{Pd}(\mathrm{II})$ (65\%). LUMO orbital was constructed from $55 \%$ of $d$-orbital of Pd(II) and $26 \%$ of $\pi$ orbitals of hzpy ligand. The $\mathrm{L}+1$ orbital is originated from $\pi$ orbitals of the hzpy ligand (73\%). Based on TDDFT, the complex exhibited an intense band $\left(\lambda_{\max }\right)$ at $282 \mathrm{~nm}$ and other peaks at 361 and $435 \mathrm{~nm}$. At $361 \mathrm{~nm}$, the transition was due to $d$ - $d$ transitions, MLCT, and n/ $\pi->\pi^{*}$ of ox ligand. The corresponding transition appeared as a shoulder at $380 \mathrm{~nm}$. The peak appeared at $435 \mathrm{~nm}$ resulting from the combination of $d-d$ and $\operatorname{MLCT}\left(\mathrm{d} \pi(\mathrm{Pd})->\pi^{*}\right.$ hzpy $)$.

In [Pd(hzpy)(ma)] complex, HOMO orbital was constructed from $64 \%$ of $\pi$ orbital of hzpy ligand in addition to $25 \%$ from $d$-orbitals of $\mathrm{Pd}(\mathrm{II})$ ion. $\mathrm{H}-1$ orbital is mainly based on $d$-orbitals of $\mathrm{Pd}(\mathrm{II})$ metal (83 \%). LUMO is based on d-orbitals of $\mathrm{Pd}(\mathrm{II})$ ion (55\%), $\pi$ orbitals of hzpy ( $26 \%$ ), and ma (18\%) ligands. $\mathrm{L}+1$ orbital is originated solely from the $\pi$ orbital of hzpy ligand (97\%). Based on TDDFT, the complex exhibited an intense band $\left(\lambda_{\max }\right)$ at $281 \mathrm{~nm}$ and other peaks at 386 and $424 \mathrm{~nm}$. At $386 \mathrm{~nm}$, the transition was due to $d$ - $d$ transitions, MLCT, and $n / \pi->\pi^{*}$ of ma ligand. The corresponding transition appeared as a shoulder at $380 \mathrm{~nm}$. The peak appeared at $424 \mathrm{~nm}$ resulting from the combination of $d-d$ and MLCT ( $\mathrm{d} \pi_{(\mathrm{Pd})}->\pi^{*}$ hzpy $)$.

In $[\operatorname{Pd}($ hzpy $)(\mathrm{pyph})]$ complex, the frontier orbitals are located mainly on the hzpy ligand. HOMO orbital is constructed from $82 \%$ of $\pi$ orbital of hzpy ligand, and $\mathrm{H}-1$ orbital is mainly based on $d$-orbitals of Pd(II) metal (91\%). LUMO is based on $d$-orbitals of $\mathrm{Pd}(\mathrm{II})$ ion $(53 \%), \pi$ orbitals of hzpy (27\%), and pyph (21\%) ligands. $L+1$ orbital is originated solely from the $\pi$ orbital of hzpy ligand ( $97 \%$ ). Based on TDDFT, the complex exhibited an intense band $\left(\lambda_{\max }\right)$ at $278 \mathrm{~nm}$ and other peaks at 382 and $466 \mathrm{~nm}$. At $382 \mathrm{~nm}$, the transition was due to $d-d$ transitions, MLCT, and $\mathrm{n} / \pi->\pi^{*}$ of ma ligand. The corresponding transition appeared as a shoulder at $365 \mathrm{~nm}$. The peak appeared at $466 \mathrm{~nm}$ resulting from the combination of $d-d$ and MLCT $\left(\mathrm{d} \pi_{(\mathrm{Pd})}->\pi^{*}\right.$ hzpy).

Natural Bond Orbital (NBO) calculations [52] were performed at the B3LYP/SDD level of theory. Donations from dinitrogen ligands to $\mathrm{Pd}(\mathrm{II})$ exceeded back donations from metal to ligand and the charges on the palladium are lower than the formal +2 charge; 0.390 for complex with hzpy ligand and $\mathrm{Cl}$ ions. The charges on the palladium ions were $0.668,0.668$ and 0.711 for complexes based on hzpy ligand with ox, ma and pyph ligands, respectively. [53] According to the NBO analysis for the palladium complexes, the electronic configurations of the Pd atom are the following: [Pd(hzpy)(ox)] complex: [core] $4 d_{x y} 1.13937,4 d_{x z}$ 1.97591, $4 d_{y z}$ 1.977308, $4 d_{x 2-y 2} 1.72177,4 d_{z 2}$ 1.96300. [Pd(hzpy)(ma)] complex: [core] $4 d_{x y} 1.24526,4 d_{x z} 1.97022,4 d_{y z}$ 1.89940, 4d $d_{x 2-y 2}$ 1.70424, $4 d_{z 2}$ 1.95074. [Pd(hzpy)(pyph)] complex: [core] $4 d_{x y} 1.53420,4 d_{x z}$ $1.95535,4 d_{y z} 1.87690,4 d_{x 2-y 2} 1.51599,4 d_{z 2} 1.92823$. The total palladium valence populations are $8.77,8.76$ and 8.81 for [Pd(hzpy)(ox)], [Pd(hzpy)(ma)] and [Pd(hzpy)(pyph)] complexes, respectively.

The molecular electrostatic potentials (MEPs) were used to highlight the negative (red) and positive (blue) regions of each complex [54]. The reddish areas were located mainly on the oxalate, malonate, and pyrophosphate ligands (Figures 16 - 18). 


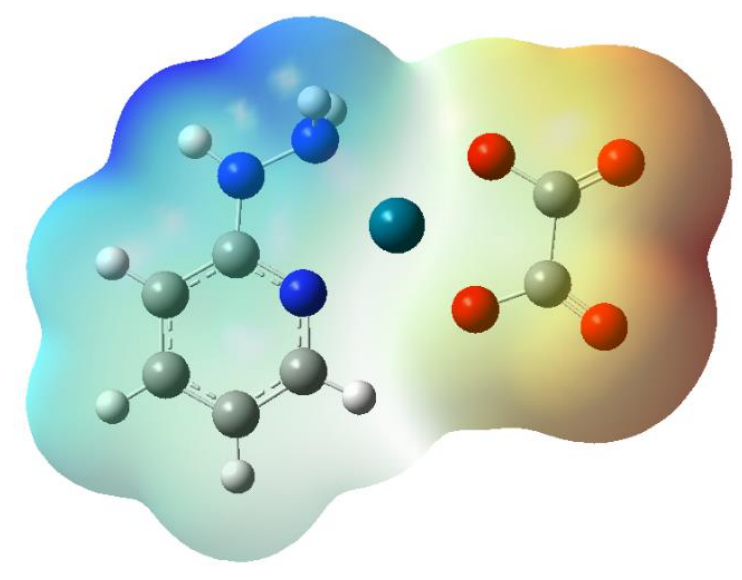

Figure 16. MEP mapping $[\operatorname{Pd}(\mathrm{hzpy})(\mathrm{ox})]$ complex.

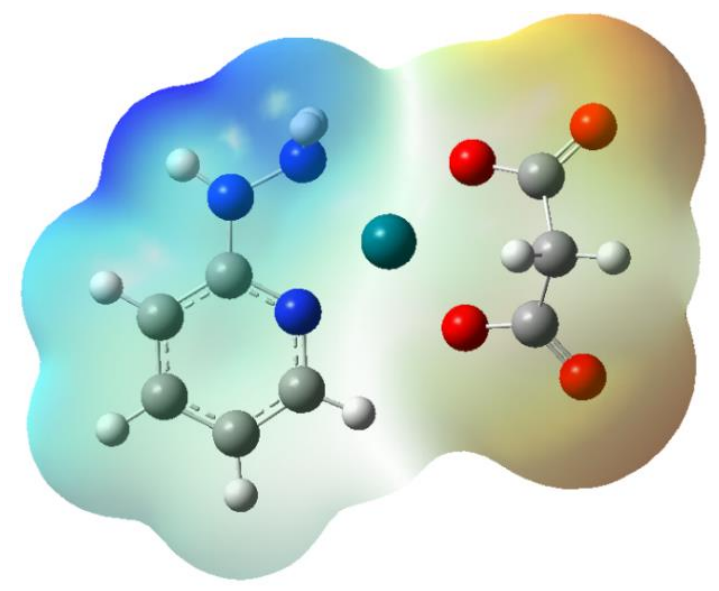

Figure 17. MEP mapping $[\mathrm{Pd}(\mathrm{hzpy})(\mathrm{ma})]$ complex.

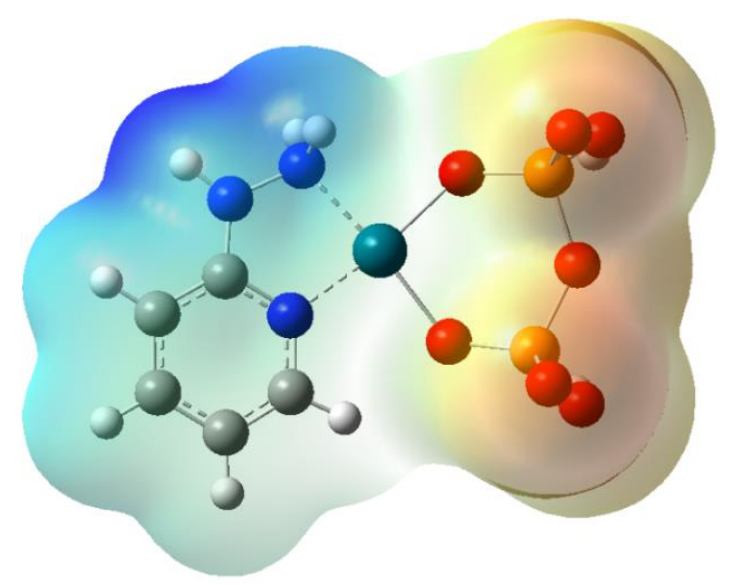

Figure 18. MEP mapping $[\operatorname{Pd}($ hzpy $)($ pyph) $]$ complex.

\subsection{Cytotoxicity.}

The in vitro cytotoxicity of the three palladium complexes against four cancer cell lines (MCF-7, HEPG-2, PC-3, and HEP-2) was investigated through the literature's method, and the $\mathrm{IC}_{50}$ values are tabulated summarized in Table 7 . Vinblastine sulfate was used as a standard (Table 7). The relation between the complex concentration and the corresponding surviving cells was plotted to obtain each tumor cell line's survival curve after treatment with each complex (Figures S8 - S11; Supplementary materials). The IC50 values were calculated from the graphs of the dose-response curve for each conc. using Graphpad Prism software (San Diego, CA. USA). The IC50 values of the [Pd(hzpy)(ox)] complex were relatively low and close 
to that of the Vinblastine sulfate. It is worth noting that the three complexes exhibited an excellent performance against PC-3 cell line, the IC50 values were: $2.87,29.5$, and $14.9 \mu \mathrm{g} / \mathrm{ml}$ for $[\mathrm{Pd}(\mathrm{hzpy})(\mathrm{ox})],[\mathrm{Pd}(\mathrm{hzpy})(\mathrm{ma})]$ and $[\mathrm{Pd}(\mathrm{hzpy})(\mathrm{pyph})]$, respectively, compared to that of Vinblastine sulfate $(42.4 \mu \mathrm{g} / \mathrm{ml})$. [Pd(hzpy)(ox)] complexes showed the lowest IC50 values against the four cancer cell lines, which may be resulted from the formation of the stable species of the complex in contrast to $[\mathrm{Pd}(\mathrm{hzpy})(\mathrm{ma})]$ complex, which may suggest a role of the methylene group in such behavior in reducing of the cytotoxic activities.

Table 7. $\mathrm{IC}_{50}$ values of the antitumor activities of the palladium complexes.

\begin{tabular}{l|c|c|c|c} 
Complex & HEP-2 & PC-3 & MCF-7 & HEPG-2 \\
\hline Vinblastine sulfate & 29.9 & 42.4 & 5.9 & 2.93 \\
\hline$[\operatorname{Pd}($ hzpy)(ox) $]$ & 14.2 & 2.87 & 6.87 & 3.39 \\
\hline$[\operatorname{Pd}($ hzpy)(ma) $]$ & 55.8 & 29.5 & 46.9 & 28.4 \\
\hline$[\operatorname{Pd}($ hzpy)(pyph) $]$ & 41.4 & 14.9 & 30.7 & 21.3
\end{tabular}

\section{Conclusions}

Three water-soluble Pd(II) complexes based on 2-hydrazinopyridine were prepared and characterized. The 2-hydrazinopyridine ligand was coordinated via the two amino groups. The malonate, oxalate, and pyrophosphate acted as a bidentate ligand and were coordinated via oxygen atoms. Spectroscopic and magnetic analyses conformed that the palladium complexes were square planar and diamagnetic. The thermal stability of the complexes was studied. DFT calculations were performed to study the theoretical properties of the complexes in the gas phase. The theoretical investigations also suggested that the complexes were stable. $\left[\operatorname{Pd}\left(\right.\right.$ hzpy)(ox)] complexes showed the lowest $\mathrm{IC}_{50}$ values against the four cancer cell lines, which may be resulted from the formation of the stable species of the complex. The three complexes exhibited enhanced cytotoxic activity against PC-3 cancer cell lines than the standard (Vinblastine sulfate). The IC50 values of the complexes were 2.87, 29.5, 14.9 and 42.4 for [Pd(hzpy)(ox)], [Pd(hzpy)(ox)], [Pd(hzpy)(ox)] and Vinblastine sulfate, respectively. Further investigations are required for correlating the antitumor activities and structure of the complexes.

\section{Funding}

This research received no external funding

\section{Acknowledgments}

This research has no acknowledgment.

\section{Conflicts of Interest}

No conflict of interest as declared by the authors.

\section{References}

1. Soliman, A.A.; Amin, M.A.; Sayed, A.M.; Abou-Hussein, A.A.A.; Linert, W. Cobalt and copper complexes with formamidine ligands: Synthesis, crystal X-ray study, DFT calculations and cytotoxicity. Polyhedron 2019, 161, 213-221, https://doi.org/10.1016/j.poly.2018.12.020.

2. Espino, J.; Fernández-Delgado, E.; Estirado, S.; de la Cruz-Martinez, F.; Villa-Carballar, S.; ViñuelasZahínos, E.; Luna-Giles, F.; Pariente, J.A. Synthesis and structure of a new thiazoline-based palladium(II) complex that promotes cytotoxicity and apoptosis of human promyelocytic leukemia HL-60 cells. Sci. Rep. 2020, 10, 16745, https://doi.org/10.1038/s41598-020-73488-0. 
3. Oliveira, C.G.; Romero-Canelón, I.; Coverdale, J.P.C.; Maia, P.I.S.; Clarkson, G.J.; Deflon, V.M.; Sadler, P.J. Novel tetranuclear PdII and PtII anticancer complexes derived from pyrene thiosemicarbazones. Dalton Transactions 2020, 49, 9595-9604, https://doi.org/10.1039/D0DT01133A.

4. Carneiro, T.J.; Martins, A.S.; Marques, M.P.M.; Gil, A.M. Metabolic Aspects of Palladium(II) Potential AntiCancer Drugs. Front. Oncol. 2020, 10, 2218, https://doi.org/10.3389/fonc.2020.590970.

5. Bellemin-Laponnaz, S. N-Heterocyclic Carbene Platinum Complexes: A Big Step Forward for Effective Antitumor Compounds. Eur. J. Inorg. Chem. 2020, 2020, 10-20, https://doi.org/10.1002/ejic.201900960.

6. Tokgun, O.; Karakas, D.E.; Tan, S.; Karagür, E.R.; İnal, B.; Akca, H.; Durap, F.; Baysal, A.; Aydemir, M. Novel ruthenium and palladium complexes as potential anticancer molecules on SCLC and NSCLC cell lines. Chemical Papers 2020, 74, 2883-2892, https://doi.org/10.1007/s11696-020-01129-x.

7. Sajadiyeh, E.; Tabatabaee, M.; Seifati, S.M.; Derikvand, Z. Cytotoxic Effect of Palladium(II) Complex with 4-Amino-5-Methyl-2H-1,2,4-Triazole-3(4H)-Thione Ligand on MCF-7 Cell Line. Pharm. Chem. J. 2020, 54, 145-147, https://doi.org/10.1007/s11094-020-02171-5.

8. Omondi, R.O.; Bellam, R.; Ojwach, S.O.; Jaganyi, D.; Fatokun, A.A. Palladium(II) complexes of tridentate bis(benzazole) ligands: Structural, substitution kinetics, DNA interactions and cytotoxicity studies. J. Inorg. Biochem. 2020, 210, 111156, https://doi.org/10.1016/j.jinorgbio.2020.111156.

9. Mbugua, S.N.; Sibuyi, N.R.S.; Njenga, L.W.; Odhiambo, R.A.; Wandiga, S.O.; Meyer, M.; Lalancette, R.A.; Onani, M.O. New Palladium(II) and Platinum(II) Complexes Based on Pyrrole Schiff Bases: Synthesis, Characterization, X-ray Structure, and Anticancer Activity. ACS Omega 2020, 5, 14942-14954, https://doi.org/10.1021/acsomega.0c00360.

10. Bošković, M.; Franich, A.A.; Rajković, S.; Jovanović, M.; Jurisević, M.; Gajović, N.; Jovanović, M.; Arsenijević, N.; Jovanović, I.; Živković, M.D. Potential Antitumor Effect of Newly Synthesized Dinuclear1,5-Naphthyridine-Bridging Palladium(II) Complexes. ChemistrySelect 2020, 5, 10549-10555, https://doi.org/10.1002/slct.202002350.

11. Budzisz, E.; Miernicka, M.; Lorenz, I.-P.; Mayer, P.; Krajewska, U.; Rozalski, M. Synthesis and X-ray structure of platinum(II), palladium(II) and copper(II) complexes with pyridine-pyrazole ligands: Influence of ligands' structure on cytotoxic activity. Polyhedron 2009, 28, 637-645, https://doi.org/10.1016/j.poly.2008.12.013.

12. Czarnomysy, R.; Radomska, D.; Muszyńska, A.; Hermanowicz, J.M.; Prokop, I.; Bielawska, A.; Bielawski, K. Evaluation of the Anticancer Activities of Novel Transition Metal Complexes with Berenil and Nitroimidazole. Molecules 2020, 25, https://doi.org/10.3390/molecules25122860.

13. Alinaghi, M.; Karami, K.; Shahpiri, A.; nasab, A.K.; Momtazi-Borojeni, A.A.; Abdollahi, E.; Lipkowski, J. A Pd(II) complex derived from pyridine-2-carbaldehyde oxime ligand: Synthesis, characterization, DNA and BSA interaction studies and in vitro anticancer activity. J. Mol. Struct. 2020, 1219, 128479, https://doi.org/10.1016/j.molstruc.2020.128479.

14. Omondi, R.O.; Ojwach, S.O.; Jaganyi, D. Review of comparative studies of cytotoxic activities of Pt(II), $\mathrm{Pd}(\mathrm{II}), \mathrm{Ru}(\mathrm{II}) /(\mathrm{III})$ and $\mathrm{Au}(\mathrm{III})$ complexes, their kinetics of ligand substitution reactions and DNA/BSA interactions. Inorg. Chim. Acta 2020, 512, 119883, https://doi.org/10.1016/j.ica.2020.119883.

15. Jung, Y.; Lippard, S.J. Direct Cellular Responses to Platinum-Induced DNA Damage. Chem. Rev. 2007, 107, 1387-1407, https://doi.org/10.1021/cr068207j.

16. Małecki, J.G.; Maroń, A. Spectroscopic, structure and DFT studies of palladium(II) complexes with pyridinetype ligands. Transition Met. Chem. 2011, 36, 297-305, https://doi.org/10.1007/s11243-011-9469-z.

17. Ferraz, K.S.O.; Ferandes, L.; Carrilho, D.; Pinto, M.C.X.; Leite, M.d.F.; Souza-Fagundes, E.M.; Speziali, N.L.; Mendes, I.C.; Beraldo, H. 2-Benzoylpyridine-N(4)-tolyl thiosemicarbazones and their palladium(II) complexes: Cytotoxicity against leukemia cells. Biorg. Med. Chem. 2009, 17, 7138-7144, https://doi.org/10.1016/j.bmc.2009.08.063.

18. Islami-Moghaddam, M.; Mansouri-Torshizi, H.; Divsalar, A.; Saboury, A.A. Synthesis, characterization, cytotoxic and DNA binding studies of diimine Platinum(II) and Palladium(II) complexes of short hydrocarbon chain ethyldithiocarbamate ligand. Journal of the Iranian Chemical Society 2009, 6, 552-569, https://doi.org/10.1007/BF03246535.

19. Paul A. K., Srivastava T.S., Chavan S. J., Chitnis M.P., Desai S., and Rao K.K., Synthesis, Characterization, Cytotoxic, and DNA Binding Studies of Some Platinum(II) Complexes of 1,2-Diamine and a-Diimine with 2-Pyridinecarboxylate Anion. J. Inorg. Biochem. 1996, 61, 179-196,

20. de Moura, T.R.; Zanetti, R.D.; Silva, D.E.S.; de Farias, R.L.; Mauro, A.E.; Pereira, J.C.M.; de Souza, A.A.; da Silva Siqueira, F.; de Souza Júdice, W.A.; Lima, M.A.; Rocha, F.V.; Deflon, V.M.; Vieira de Godoy Netto, A. Palladium(ii) complexes bearing 1-iminothiolate-3,5-dimethylpyrazoles: synthesis, cytotoxicity, DNA binding and enzymatic inhibition studies. New J. Chem. 2020, 44, 19891-19901, https://doi.org/10.1039/D0NJ02825H.

21. Anu, D.; Naveen, P.; Rath, N.P.; Kaveri, M.V. Palladium (II) complexes containing substituted thiosemicarbazones. Synthesis, spectral characterization, X-ray crystallography, biomolecular interactions and in vitro cytotoxicity. J. Mol. Struct. 2020, 1206, 127703, https://doi.org/10.1016/j.molstruc.2020.127703.

22.. Ayyannan, G.; Mohanraj, M.; Gopiraman, M.; Uthayamalar, R.; Raja, G.; Bhuvanesh, N.; Nandhakumar, R.; Jayabalakrishnan, C. New Palladium(II) complexes with ONO chelated hydrazone ligand: Synthesis, 
characterization, DNA/BSA interaction, antioxidant and cytotoxicity. Inorg. Chim. Acta 2020, 512, 119868, https://doi.org/10.1016/j.ica.2020.119868.

23. Becke, A.D. Density-functional thermochemistry. III. The role of exact exchange. The Journal of Chemical Physics 1993, 98, 5648-5652, https://doi.org/10.1063/1.464913.

24. Lee, C.; Yang, W.; Parr, R.G. Development of the Colle-Salvetti correlation-energy formula into a functional of the electron density. Physical Review B 1988, 37, 785-789, https://doi.org/10.1103/PhysRevB.37.785.

25. Chen W-S and Chen Z-R, Quantum chemical study on asymmetric allylation of benzaldehyde in the presence of chiral allylboronate. J Zhejiang Univ Sci B. 2005, 6(6), 606-610, https://doi.org/10.1631/jzus.2005.B0606.

26. Dikmen, G.; Hür, D. Palladium (II) complex: Synthesis, spectroscopic studies and DFT calculations. Chem. Phys. Lett. 2019, 716, 49-60, https://doi.org/10.1016/j.cplett.2018.12.018.

27. Al-Azmi, A. Synthesis, crystal analysis and DFT calculations of Ni(II) and Pd(II) complexes of 3,3'-((1,2phenylenebis(azanediyl))bis(2-oxoethane-2,1-diyl))bis(1-allyl-1H-imidazole-3-ium). J. Mol. Struct. 2019, 1180, 179-187, https://doi.org/10.1016/j.molstruc.2018.11.043.

28. M. J. Frisch, G. W. T., H. B. Schlegel, G. E. Scuseria, M. A. Robb, J. R. Cheeseman, G. Scalmani, V. Barone, B. Mennucci, G. A. Petersson, H. Nakatsuji, M. Caricato, X. Li, H. P. Hratchian, A. F. Izmaylov, J. Bloino, G. Zheng, J. L. Sonnenberg, M. Hada, M. Ehara, K. Toyota, R. Fukuda, J. Hasegawa, M. Ishida, T. Nakajima, Y. Honda, O. Kitao, H. Nakai, T. Vreven, J. A. Montgomery, Jr., J. E. Peralta, F. Ogliaro, M. Bearpark, J. J. Heyd, E. Brothers, K. N. Kudin, V. N. Staroverov, T. Keith, R. Kobayashi, J. Normand, K. Raghavachari, A. Rendell, J. C. Burant, S. S. Iyengar, J. Tomasi, M. Cossi, N. Rega, J. M. Millam, M. Klene, J. E. Knox, J. B. Cross, V. Bakken, C. Adamo, J. Jaramillo, R. Gomperts, R.E. Stratmann, O. Yazyev, A. J. Austin, R. Cammi, C. Pomelli, J. W. Ochterski, R. L. Martin, K. Morokuma, V. G. Zakrzewski, G. A. Voth, P. Salvador, J. J. Dannenberg, S. Dapprich, A. D. Daniels, O. Farkas, J. B. Foresman, J. V. Ortiz, J. Cioslowski, D. J. Fox Gaussian 09, Revision C.01, Gaussian, Inc., Wallingford CT: 2010.

29. Mosmann, T. Rapid colorimetric assay for cellular growth and survival: Application to proliferation and cytotoxicity assays. J. Immunol. Methods 1983, 65, 55-63, https://doi.org/10.1016/0022-1759(83)90303-4.

30. Riyadh, S.M.; Gomha, S.M.; Mahmmoud, E.A.; Elaasser, M.M. ChemInform Abstract: Synthesis and Anticancer Activities of Thiazoles, 1,3-Thiazines, and Thiazolidine Using Chitosan-GraftedPoly(vinylpyridine) as Basic Catalyst. ChemInform 2015, 46, https://doi.org/10.1002/chin.201538150.

31. Soliman, A.A.; Amin, M.A.; El-Sherif, A.A.; Ozdemir, S.; Varlikli, C.; Zafer, C. Synthesis and characterization of novel series of Fe(II)-mixed ligand complexes involving 2,2'-bipyridyl ligand. Dyes and Pigments 2013, 99, 1056-1064, https://doi.org/10.1016/j.dyepig.2013.08.007.

32. Soliman, A.A.; Khattab, M.M.; Linert, W. Kinetic and characterization studies of iron(II) and iron(III) complex formation reactions with hydrazinopyridine. J. Coord. Chem. 2008, 61, 2017-2031, https://doi.org/10.1080/00958970701824373.

33. Nakamoto, K., Applications in Inorganic Chemistry. In Infrared and Raman Spectra of Inorganic and Coordination Compounds, pp 149-354, https://doi.org/10.1002/9780470405840.ch2.

34. Mautner, F.A., Jantscher, P.V., Fischer, R.C. et al. Syntheses, structural characterization, and thermal behaviour of metal complexes with 3-aminopyridine as co-ligands. Transit. Met. Chem. 2020. https://doi.org/10.1007/s11243-020-00436-2.

35. Samota, M.K.; Seth, G. Synthesis, characterization, and antimicrobial activity of palladium(II) and platinum(II) complexes with 2-substituted benzoxazole ligands. Heteroat. Chem 2010, 21, 44-50, https://doi.org/10.1002/hc.20578.

36. Al-Khodir, F.A.I.; Abumelha, H.M.A.; Al-Warhi, T.; Al-Issa, S.A. New Platinum(IV) and Palladium(II) Transition Metal Complexes of s-Triazine Derivative: Synthesis, Spectral, and Anticancer Agents Studies. BioMed Research International 2019, 2019, 9835745, https://doi.org/10.1155/2019/9835745.

37. Park, S.; Kadkin, O.N.; Tae, J.-G.; Choi, M.-G. Photoresponsive palladium(II) complexes with azobenzene incorporated into benzyl aryl ether dendrimers. Inorg. Chim. Acta 2008, 361, 3063-3068, https://doi.org/10.1016/j.ica.2008.02.023.

38. Horowitz, H.H.; Metzger, G. A New Analysis of Thermogravimetric Traces. Anal. Chem. 1963, 35, 14641468, https://doi.org/10.1021/ac60203a013.

39. Nath, M.; Arora, P. Spectral and Thermal Studies of Cobalt(II), Nickel(II) and Copper(II) Complexes of Schiff Bases Obtained from o-Hydroxyacetophenone and Amino Acids. Synth. React. Inorg. Met.-Org. Chem. 1993, 23, 1523-1546, https://doi.org/10.1080/15533179308016704.

40. Coats, A.W.; Redfern, J.P. Kinetic Parameters from Thermogravimetric Data. Nature 1964, 201, 68-69, https://doi.org/10.1038/201068a0.

41. Soliman, A.A.; El-Medani, S.M.; Ali, O.A.M. Thermalstudy of chromium and molybdenum complexes with some nitrogen and nitrogen-oxygendonors ligands. J. Therm. Anal. Calorim. 2006, 83, 385-392, https://doi.org/10.1007/s10973-005-7009-9.

42. Soliman, A.A.; Taha, A.; Linert, W. Spectral and thermal study on the adduct formation between square planar nickel(II) chelates and some bidentate ligands. Spectrochimica Acta Part A: Molecular and Biomolecular Spectroscopy 2006, 64, 1058-1064, https://doi.org/10.1016/j.saa.2005.09.015. 
43. Kirsch - De Mesmaeker A., Lecomte, J. \& Kelly, J. Photoreactions of metal complexes with DNA, especially those involving a primary photo-electron transfer. In: Mattay J. (eds) Electron Transfer II. Topics in Current Chemistry, vol 177. Springer, Berlin, Heidelberg. 2005, 25-76. https://doi.org/10.1007/3-540-60110-4_2.

44. Guelai, A.; Brahim, H.; Guendouzi, A.; Boumediene, M.; Brahim, S. Structure, electronic properties, and NBO and TD-DFT analyses of nickel(II), zinc(II), and palladium(II) complexes based on Schiff-base ligands. J. Mol. Model. 2018, 24, 301, https://doi.org/10.1007/s00894-018-3839-9.

45. Zhang, X.-M.; Wu, H.-S.; Chen, X.-M. Linear and Helical Chains in Hydrothermally Synthesized Coordination Polymers [Co(bpdc)(H2O)2] and [Ni(bpdc)(H2O)3]·H2O Involving in situ Ligand Synthesis. Eur. J. Inorg. Chem. 2003, 2003, 2959-2964, https://doi.org/10.1002/ejic.200300060.

46. Jung, E.J.; Lee, U.k.; Koo, B.K. Hydrothermal synthesis and crystal structure of [Co(2,5pydc)(H2O)2]n·nH2O (2,5-pydc=2,5-pyridinedicarboxylate). Inorg. Chim. Acta 2008, 361, 2962-2966, https://doi.org/10.1016/j.ica.2008.01.029.

47. Masoudi, M.; Behzad, M.; Arab, A.; Tarahhomi, A.; Rudbari, H.A.; Bruno, G. Crystal structures, DFT calculations and Hirshfeld surface analyses of three new cobalt(III) Schiff base complexes derived from meso-1,2-diphenyl-1,2-ethylenediamine. J. Mol. Struct. 2016, 1122, 123-133, https://doi.org/10.1016/j.molstruc.2016.05.092.

48. Parr, R.G.; Pearson, R.G. Absolute hardness: companion parameter to absolute electronegativity. J. Am. Chem. Soc. 1983, 105, 7512-7516, https://doi.org/10.1021/ja00364a005.

49 Geerlings, P.; De Proft, F.; Langenaeker, W. Conceptual Density Functional Theory. Chem. Rev. 2003, 103, 1793-1874, https://doi.org/10.1021/cr990029p.

50. Parr, R.G.; Szentpály, L.v.; Liu, S. Electrophilicity Index. J. Am. Chem. Soc. 1999, 121, 1922-1924, https://doi.org/10.1021/ja983494x.

51. Sagdinc, S.; Köksoy, B.; Kandemirli, F.; Bayari, S.H. Theoretical and spectroscopic studies of 5-fluoro-isatin3-(N-benzylthiosemicarbazone) and its zinc(II) complex. J. Mol. Struct. 2009, 917, 63-70, https://doi.org/10.1016/j.molstruc.2008.06.033.

52. Mansour, A.M. Coordination behavior of sulfamethazine drug towards $\mathrm{Ru}(\mathrm{III})$ and $\mathrm{Pt}(\mathrm{II})$ ions: Synthesis, spectral, DFT, magnetic, electrochemical and biological activity studies. Inorg. Chim. Acta 2013, 394, 436445, https://doi.org/10.1016/j.ica.2012.08.025.

53. Małecki, J.G. Spectroscopic, structure, and DFT studies of cationic palladium(II) complexes with imidazole derivative ligands. J. Coord. Chem. 2013, 66, 1561-1573, https://doi.org/10.1080/00958972.2013.784903.

54. Hussain, R.; Saeed, M.; Mehboob, M.Y.; Khan, S.U.; Usman Khan, M.; Adnan, M.; Ahmed, M.; Iqbal, J.; Ayub, K. Density functional theory study of palladium cluster adsorption on a graphene support. RSC Advances 2020, 10, 20595-20607, https://doi.org/10.1039/D0RA01059F. 